\author{
Liudmyla V. Litvinova*, Sylwia Lukasik**, Danuta Żurkiewicz***, \\ Marta Gwizdała ${ }^{* * * * *}$, Maciej Chyleński ${ }^{* * * * *}$, Helena Malmström ${ }^{* * * * * *}$, \\ Mattias Jakobsson ${ }^{* * * * * * * *}$, Anna Juras ${ }^{* * * * * * * * * *}$
}

\title{
ANTHROPOLOGICAL DESCRIPTION OF SKELETAL MATERIAL FROM THE DNIESTER BARROW- CEMETERY COMPLEX, YAMPIL REGION, VINNITSA OBLAST (UKRAINE)
}

\begin{abstract}
Anthropological examinations were performed on skeletal material from four barrow necropolises located in the Yampil Region (Ukraine) and dated to the Eneolithic, Bronze Age and Iron Age. The purpose of the examinations was the determination of sex and age at death of individuals, reconstruction of their stature and assessment of their status of health. The examinations covered 61 individuals: 17 children
\end{abstract}

ABSTRACT

* Department of Bioarchaeology, Institute of Archaeology, Ukrainian Academy of Science, Geroiv Stalingrada ave. 12,04210 Kyiv, Ukraine; litvinovalv@ukr.net

** Department of Human Evolutionary Biology, Institute of Anthropology, Faculty of Biology, Adam Mickiewicz University in Poznań, Umultowska 89, 61-614 Poznań, Poland; lukasik@amu.edu.pl

*** Department of Prehistory of Central and Eastern Europe, Institute of Prehistory, Faculty of History, Adam Mickiewicz University in Poznań; Umultowska 89D, 61-614 Poznań, Poland; danuta@amu.edu.pl

**** Institute of Prehistory, Faculty of History, Adam Mickiewicz University in Poznań, Umultowska 89D, 61-614 Poznań, Poland; marta-gwizdala@wp.pl

***** Department of History, Institute of Prehistory, Faculty of History, Adam Mickiewicz University in Poznań, Umultowska 89d, 61-614 Poznań, Poland; maciejchylenski@ gmail.com

****** Department of Organismal Biology and SciLifeLab; Uppsala University, Norbyvägen 18C, SE-752 36 Uppsala, Sweden; helena.malmstrom@ebc.uu.se

******* Department of Organismal Biology and SciLifeLab, Uppsala University, Norbyvägen 18C, SE-752 36 Uppsala, Sweden; mattias.jakobsson@ebc.uu.se

******** Department of Human Evolutionary Biology, Institute of Anthropology, Faculty of Biology, Adam Mickiewicz University in Poznań, Umultowska 89, 61-614 Poznań, Poland; ajuras.anthropology@gmail.com 
and 44 adults. Their health status was assessed using four common indicators: linear enamel hypoplasia, cribra orbitalia, porotic hyperostosis and dental caries.

Key words: Eneolithic, Yamnaya culture, Bronze Age, anthropology, Ukraine In 2010-2014, a Polish-Ukrainian archaeological expedition investigated seven barrows situated on the middle Dniester, in the vicinity of the town of Yampil, Ukraine. The investigations formed part of a research project devoted to the exploration of Podolia as a cultural interchange in the 4th/3rd and 2nd millennia BC. An important aspect of the project was its interdisciplinary character which enhanced the cultural and biological picture of communities practising the barrow funerary rite.

The area of investigations probing a section of the Middle Dniester Area, administratively restricted to the Yampil Region (Vinnitsa Oblast), is characterized by a considerable concentration of barrow features. The area coincides with the north-western range of 'Early-Bronze' barrows, associated with eastern Europe's steppe and forest-steppe.

A detailed surface survey of the Yampil Region and earlier excavations carried out as part of conservation efforts helped reconstruct the cultural landscape of this space fragment. A recent summary of these efforts [Kośko et al. 2014] shows that the building of most barrows in this area can be linked to Yamnaya culture (YC) communities, while the history of their later 'use' covers successive millennia: it involves later cultural units (Catacomb culture - CC; Babyno culutre - BC and Noua culture - NC) as far as modern times. From the perspective of a single barrow, this presents a picture that is difficult to interpret for it encompasses an extensive funerary zone (cemetery), grouping successive burials, traces of ritual activities related to the cult of the dead and later funerary attempts to architecturally fashion the mound form.

About the biology of the builders and their successors of most tombs located in the area in question very little is known now. Relying on what is known about the YC eastern frontier in this context, specifically about the Middle Volga (over 1,500 km NE of Yampil), it can be concluded that the representatives of Yampil communities were taller and heavier than average. The results of investigations hitherto carried out show that about 40 per cent of individuals inhabiting the area under discussion in the Early Bronze Age had cribra orbitalia ${ }^{1}$. Interestingly enough, for earlier and later communities the figure is only about 10 per cent. In addition, the 'Yamnaya' community on the Middle Volga was characterized by an almost absolute absence of caries [Anthony 2007: 326].

The high frequency of cribra orbitalia and low frequency of dental caries could have resulted, in the opinion of Anthony [2007], from the diet of mostly car-

\footnotetext{
${ }^{1}$ Resulting from iron deficiency, among other reasons.
} 


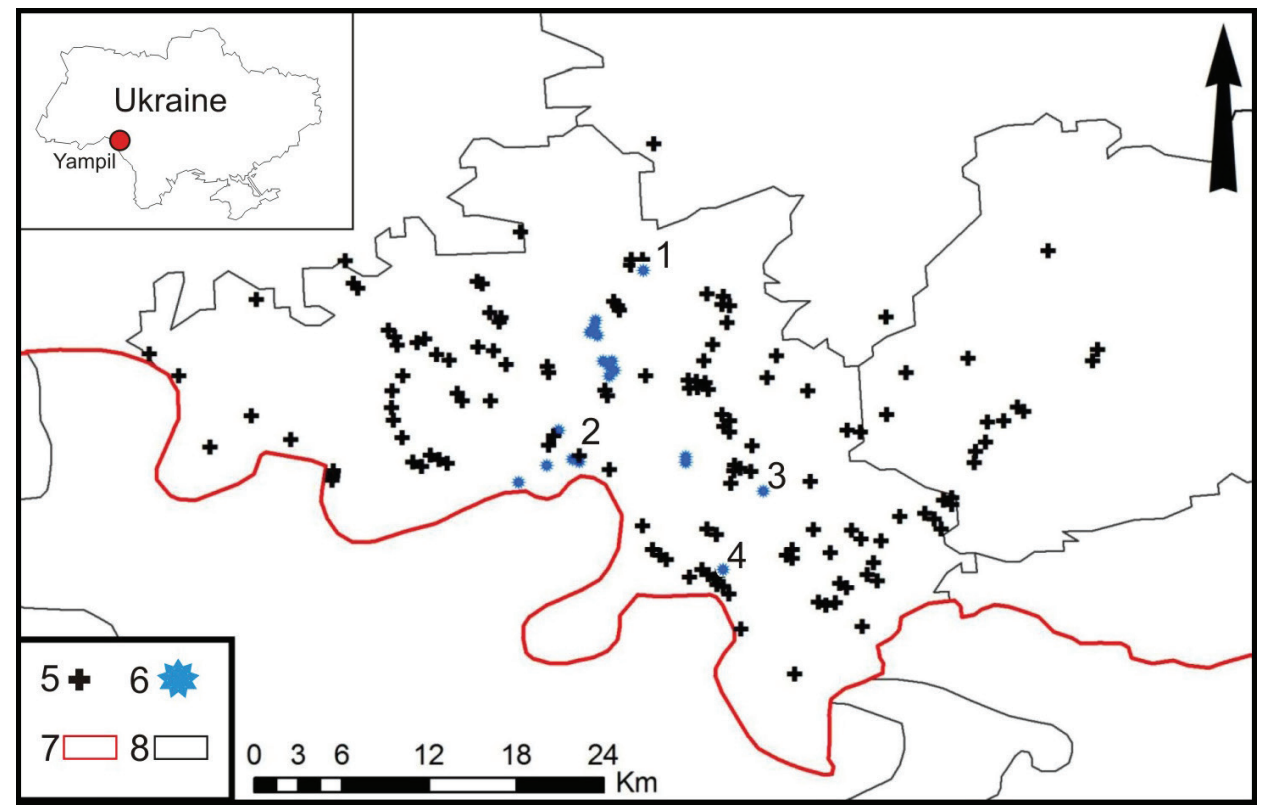

Fig . 1. Map of Yampil barrows, showing administrative borders: 1 - Klembivka barrow 1; 2 Porohy, barrow 3A; 3 - Pidlisivka, barrow 1; 4 - Prydnistryanske, barrows 1-4; 5 - barrows; 6 - excavated barrows; 7 - Ukrainian-Moldovan frontier; 8 - Yampil Region border

bohydrate-poor (cereals) and protein-rich foods (blocking the assimilation of iron). The diet of past populations was strongly tied to their economic and settlement system. Mobile animal herding involving movement along large distances in wagons or on horseback supposedly resulted in the absence of any larger permanent settlements. Consequently, these populations' daily diet had only a small share of cereal products.

These observations correspond well to the widely adopted picture of YC communities, held to have consisted of patriarchal itinerant nomads-herders, living on a diet of mainly animal products, as well as mounted warriors defending their possessions.

Only slightly visible or totally obliterated today, mound forms were once a significant element of cultural landscapes, being loci around which everyday life centred. The study of central burials, around which the mound structure was formed and the other funeral space was built, indicates the dominant position of adult males to which barrows were dedicated. The patrilineal and patrilocal character of these communities follows also from the linguistic studies of Proto-Indo-European vocabulary [Anthony 2007: 304].

It is very hard to decide if a barrow was treated as a family cemetery and whether all the members of a given family were entitled to be buried in it. The 
examination results of mtDNA fragments belonging to individuals from barrow 1, the Pidlisivka site (features 1A and 11), point to the possibility of relationship in the female line between two males buried in the central grave and in a feature placed underneath the mound later [Juras 2014]. However, to build a complete picture of the social structure and funerary rites of this community, more research is necessary.

The sites from which the studied material comes are located on the left bank of the Dniester. The barrows in Prydnistryanske (site 1, barrows I-IV) and Porohy (barrow 3A) lie on the edge of the river valley, while the barrows from Pidlisivka (barrow 1) and Klembivka (barrow 1) are located in the drainage basins of smaller watercourses emptying into the Dniester. The distances between particular sites are small, ranging from 7 to $22 \mathrm{~km}$ (Fig. 1). When the archaeological investigations began most mounds had already been largely levelled off. Their diameter ranged from about 25 to $49 \mathrm{~m}$, while their height stayed between almost $1 \mathrm{~m}$ to about $4 \mathrm{~m}$. By far, the greatest surviving height was that of barrow IV from Prydnistryanske. Features from this site, associated with the Eneolithic populations of the Gordinesți group of the Tripolye culture (TC-G) and the Early Bronze YC make up the most developed chronological sequence of the ceremonial-funerary centre the beginnings of which are dated to the second half of the 4th millennium BC, while the decline of continuous use falls on the first half of the 3rd millennium BC. It grew in importance, however, yet again in the Iron Age. The chronology of the other sites also fits into the mentioned time interval [Goslar et al. 2015], adding to this sequence the burials of the Babyno and Noua communities from the 2nd millennium BC.

The skeletal material from the above-named sites were studied to determine sex and age at death as well as to reconstruct the stature of particular individuals and evaluate their status of health.

1. DESCRIPTION OF SOURCES

Analyses were performed altogether on 61 individuals: 13 from Pidlisivka 1, 11 from Klebivka 1, 20 from Porohy 3A and 17 from Prydnistryanske 1. There were far more adults than children (Tab. 1 and Supplement 1). The skeletal material was poorly preserved and incomplete for the most part, which greatly limited research possibilities. Out of all individuals, only 23 could be subjected to the examination of cribra orbitalia (36.5\%), 11 to porotic hyperostosis (17.5\%), 21 to linear enamel hypoplasia (33.3\%) and 30 to dental caries (47.6\%) (see Supplement 2). 
Number of individuals studied

\begin{tabular}{|l|l|l|l|l|l|l|}
\hline \multirow{2}{*}{ Site } & \multicolumn{2}{|c|}{ Children } & \multicolumn{2}{c|}{ Adults } & \multicolumn{2}{c|}{ Total } \\
\cline { 2 - 7 } & N & \% & N & \% & N & \% \\
\hline Pidlisivka 1 & 6 & 35.3 & 7 & 15.9 & 13 & 21.3 \\
\hline Klembivka 1 & 3 & 17.6 & 8 & 18.2 & 11 & 18.0 \\
\hline Porohy 3A & 5 & 29.4 & 15 & 34.1 & 20 & 32.8 \\
\hline Prydnistryanske 1 & 3 & 17.6 & 14 & 31.8 & 17 & 27.9 \\
\hline Total & 17 & 27.9 & 44 & 72.1 & 61 & 100 \\
\hline
\end{tabular}

2. ANTHROPOLOGICAL METHODS

Age at death and sex of individuals were determined using standard anthropological methods [Baker et al. 2005; Buikstra, Ubelaker 1994; Schaefer et al. 2009; White, Folkens 2005].The age of subadults was determined by evaluating the tooth development and eruption, skeleton ossification as well as bone measurements. The age of adults, in turn, was determined on the basis of the degree of obliteration of cranial sutures, the tooth wear and changes on the surface of the pubic symphysis. It was necessary to use various methods of age determination because the skeletal material was rather poorly preserved and incomplete. The sex of adult individuals was determined, referring to the morphological characteristics of the skull and pelvis. Additionally, a molecular determination of sex assignment was performed for some of the individuals, in particular for infants and juveniles as well as for those specimens where anthropological sex determination was uncertain (see ancient DNA analysis).

For the purpose of evaluating the state of health, the following indicators were used: linear enamel hypoplasia (LEH), cribra orbitalia (CO), porotic hyperostosis (PH) and dental caries. Hypoplastic defects were assessed on incisors, canines, and premolars according to the recommendations of Goodman and Rose [1990]. To assess the age of particular lines, the method of Goodman and Rose [1990] was used. The degree of intensity of cribra orbitalia was assessed by applying the active/healing scale together with the scale of the Global History of Health Project (GHHP) [Steckel et al. 2005]. The degree of intensity of PH was also assessed by applying the GHHP scale [Steckel et al. 2005]. Caries was assessed on all tooth categories, both deciduous and permanent. Teeth were examined macroscopically without using any magnifying instruments. 
Furthermore, data on injuries, degenerative lesions and inflammations, were collected together with information on other pathologies of the masticatory organ (dental calculus and abscesses). With respect to adult individuals, their stature was reconstructed, using the method developed by Trotter and Gleser [1952].

\subsection{ANCIENT DNA ANALYSIS}

Samples. In order to obtain molecular determination of sex, we performed ancient DNA (aDNA) analysis of 10 specimens from archaeological sites in Pidlisivka 1 (2 individuals), Porohy 3A ( 2 individuals), Klembivka 1 (2 individuals) and Prydnistryanske 1 (4 individuals). Two intact teeth from each individual were collected using gloves and face masks to minimize the possibility of contaminations from modern humans. Molecular studies were conducted in the laboratory, at the Adam Mickiewicz University in Poznan, which is dedicated exclusively to the analysis of ancient DNA. All the precautions against modern DNA contaminations were taken as described earlier [Juras et al. 2014].

DNA extraction and library preparation. Prior to the extraction of a DNA, each tooth was cleaned with the use of $\sim 5 \% \mathrm{NaOCl}$, followed by UV irradiation and drilling with Dremel ${ }^{\circledR}$ drill bits. DNA was extracted using the silica-based method according to Yang et al. [1998], modified by adding urea as in Svensson et al. [2008]. Twenty microliters of DNA were used to build blunt-end libraries [Mayer and Kircher 2010], skipping the initial nebulization step. Amplification and purification was conducted as in [Günther et al. 2015] with minor modifications. Concentrations and length distribution of DNA fragments were estimated using High Sensitivity D1000 Screen Tape assay on 2200 Tape Station system (Agilent). DNA libraries were shotgun sequenced on Illumina's HiSeq2500 (1250bp, pair end) or on Hi Seq X Ten (150bp, paired-end) at the SNP \& SEQ technology platform Sci Life Sequencing Centre in Uppsala, Sweden. Obtained paired-end reads were demultiplexed, merged, and trimmed. The merged and trimmed reads were subsequently mapped to the human reference genome using BWA [ $\mathrm{Li}$, Durbin 2009]. The reads were then filtered for duplicates using Python scripts provided by Kircher [2012], and all reads with a minimum length of 35 base pairs were analyzed using same tools [Li et al. 2009].

Molecular sexing. Molecular sex was determined using the method of Skoglund et al. [2013] based on the analysis of the ratio of sequence reads mapping to $\mathrm{Y}$ and $\mathrm{X}$ chromosomes $\left(\mathrm{R}_{\mathrm{y}}\right)$ and restricted only to reads with mapping qualities of at least 30 . 
3. RESULTS

3.1. PIDLISIVKA 1

From the Pidlisivka 1 site, skeletal material belonging to 13 individuals were recovered: seven adults and six children (Tab. 2) [Bednarek et al. 2014; Klochko et al. 2015a].

\subsubsection{ENEOLITHIC BURIALS}

\section{Barrow 1, feature $1 b$}

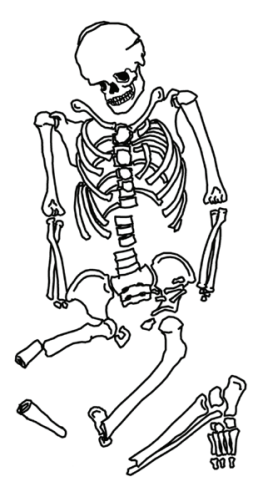

A poorly-preserved skeleton with a damaged skull. The preserved bones include large skull fragments, including facial bones, large fragments of lower and upper limb bones, small fragments of the pelvis, the sternum, scapula, foot bones, vertebrae and ribs. The skeleton belonged to a male aged 22-25 years (adultus). The molecular analysis corroborated the morphological sex assessment. Due to the poor state of preservation of long bones, it was not possible to reconstruct his stature.

Palaeopathological lesions: LEH on the upper left medial incisor (age of the individual at the time of defect: 2.5-3.0 years); a deformation of the left mastoid process.

Barrow 1, feature 10

A poorly-preserved skeleton with a badly damaged

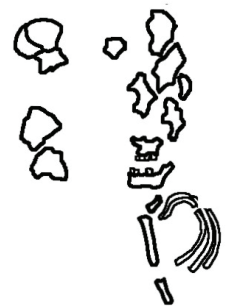
skull. The preserved bones include small fragments of the cranial vault, maxillae and the mandible, as well as vertebrae and ribs. The skeleton belonged to a child aged 0-9 months (infans I). No palaeopathological lesions were observed.

\&్య 
Barrow 1, feature 1a
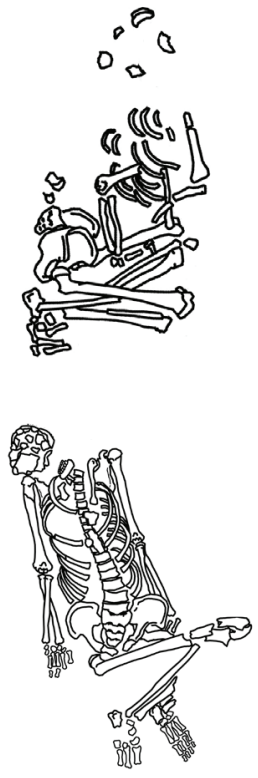

Skeleton 1. A poorly-preserved skeleton with a badly damaged skull. Three small fragments of cranial vault bones and lower and upper limb bones have been preserved. The skeleton belonged to a child aged 7-8 years (infans II). No palaeopathological lesions were observed.

Skeleton 2. A poorly-preserved skeleton with a badly damaged skull. Small fragments of cranial bones (cranial vault and mandible) were recovered together with the bones of upper and lower limbs and fragments of the pelvis. The skeleton belonged to a male aged 30-40 years (adultus/maturus). Due to the poor state of preservation of long bones, it was not possible to reconstruct his stature.

Palaeopathological lesions: dental calculus, degenerative lesions at proximal and distal ends of tibiae and femora.

Barrow 1, feature 9

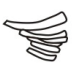

0

A poorly-preserved skeleton with a badly damaged skull. The preserved skeletal material include small fragments of skull and long bones (ulna and tibia) and a fragment of a scapula. The skeleton belonged to a child aged 0-1 years (infans I). No palaeopathological lesions were observed.

Barrow 1, feature 11

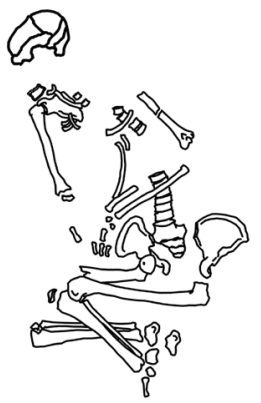

A poorly-preserved skeleton with a badly damaged skull. The preserved bones include small fragments of the cranial vault and the mandible, as well as small fragments of upper and lower limb bones and the pelvis. The skeleton belonged to a male aged 35-40 years (maturus). Due to the poor state of preservation of long bones, it was not possible to reconstruct his stature.

Palaeopathological lesions: dental calculus; considerable lowering of alveolar processes 
Barrow 1, feature 5

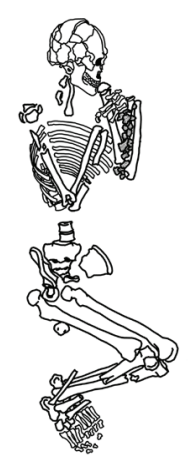

A poorly-preserved skeleton with a badly damaged skull. The preserved bones include small fragments of the skull (bones of the cranial vault and the facial skeleton), large fragments of long bones, small fragments of the pelvis, ribs and foot bones. The skeleton belonged to a male aged 30-35 years (adultus). Due to the poor state of preservation of long bones, it was not possible to reconstruct his stature.

Palaeopathological lesions: LEH on both upper incisors, the right upper first premolar and right lower canine (age of the individual at the time of respective defects: $3.5-4.0,2.5-$ -3.0, 2.5-3.0years).

\section{Barrow 1, feature 13}

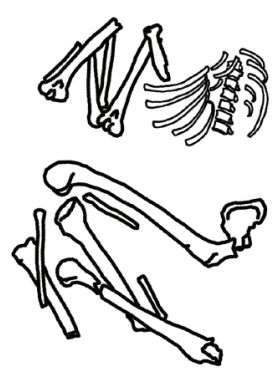

A poorly-preserved skeleton with a badly damaged skull. The preserved bones include small fragments of the skull (bones of the cranial vault and maxillae), large fragments of upper and lower limb bones (epiphyses are damaged). The skeleton most probably belonged to a female aged 20-25 years (adultus). The molecular analysis corroborated the morphological sex assessment. Due to the poor state of preservation of long bones, it was not possible to reconstruct her stature. No palaeopathological lesions were observed.

\subsubsection{CATACOMB CULTURE BURIAL}

\section{Barrow 1, feature 4}

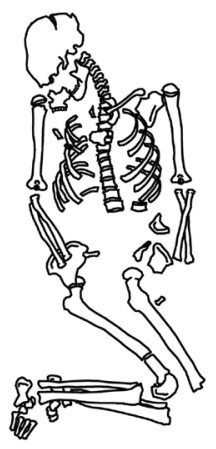

A poorly-preserved skeleton with a badly damaged skull. The preserved bones include small fragments of the cranial vault, fragments of upper limb bones, small fragments of the pelvis, ribs, vertebrae and foot bones. The skeleton belonged to a child aged 11-12 years (infans II).

Palaeopathological lesions: LEH on the upper left canine and lower right first premolar (age of the individual at the time of both defects: 4.5-5.0 years). 
Barrow 1, feature 7

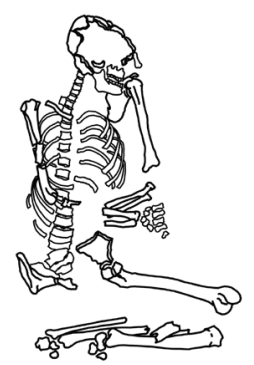

A poorly-preserved skeleton with a badly damaged skull. The preserved bones include small fragments of the cranial vault, a small fragment of the mandible, as well as small fragments of upper and lower limb bones. The skeleton could have belonged to a male aged 25-30 years (adultus). Due to the poor state of preservation of long bones, it was not possible to reconstruct his stature.

Palaeopathological lesions: dental calculus; LEH on all upper premolars and lower first premolars (age of the individual at the time of respective defects: 5.0-5.5, 4.5-5.0, 4.5-5.0, 4.5-5.0, 4.0-4.5, 3.5-4.0 years); injury sustained during the individual's lifetime recorded on a small fragment of the nasal bone (no traces of inflammation were recorded).

3.1.5. IRON AGE BURIAL

\section{Barrow 1, feature 12}

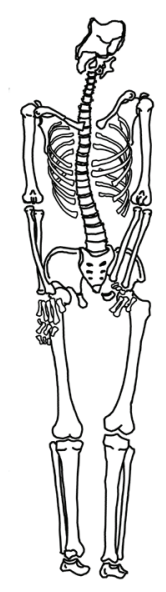

A well-preserved skeleton with a badly damaged skull. The preserved bones include small fragments of the cranial vault (occipital bone and left parietal bone), a small fragment of the mandible, as well as large fragments of upper and lower limb bones, pelvis, foot bones, phalanges, vertebrae and ribs. The skeleton belonged to a male aged 50-55 years (maturus). Due to the poor state of preservation of long bones, it was not possible to reconstruct his stature.

Palaeopathological lesions: the upper left second molar showed signs of caries; thoracic vertebrae had Schmorl's nodes, while lumbar vertebrae carried Schmorl's nodes and osteophytes; dental calculus and a considerable lowering of alveolar processes could be observed. The upper left third molar was lost antemortem. On the left maxilla, over the upper second molar, dental abscesses were recorded. Degenerative lesions of the left acetabulum of the hip joint, proximal end of a hand phalanx and ribs were observed.

\section{Barrow 1, mound}

A poorly-preserved skeleton with a badly damaged skull. The preserved bones include a fragment of the right temporal bone and maxilla, small fragments of the 
scapula and pelvis, large fragments of upper and lower limb bones (epiphyses are not fused). The skeleton belonged to an individual aged 15-20 years (juvenis).

Palaeopathological lesions: dental calculus.

Barrow 1, feature 8

A poorly-preserved skeleton:a fragment of the right femur, a small fragment of the ulna and fine fragments of ribs were recorded. The skeleton belonged to a child aged 1-6 years (infans I). No palaeopathological lesions were observed.

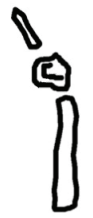

Ta b e 2

Basic information on skeletal material from barrow 1, Pidlisivka site

\begin{tabular}{|c|c|c|c|c|c|}
\hline Site & Grave & $\begin{array}{l}\text { Anthropologi- } \\
\text { cal Age } \\
\text { Determination }\end{array}$ & $\begin{array}{l}\text { Anthropo- } \\
\text { logical Sex } \\
\text { Assignment }\end{array}$ & $\begin{array}{l}\text { Molecular } \\
\text { Sex } \\
\text { Assignment }\end{array}$ & $\begin{array}{l}\text { Archaeological } \\
\text { Culture }\end{array}$ \\
\hline Pidlisivka & Mound & $\begin{array}{l}\text { Juvenis } \\
\text { (15-20 years) }\end{array}$ & --- & Not done & $?$ \\
\hline Pidlisivka & $\begin{array}{l}\text { Feature 1a } \\
\text { Skeleton } 1\end{array}$ & $\begin{array}{l}\text { Infans II } \\
\text { (7-8 years) }\end{array}$ & --- & Not done & $\mathrm{YC}$ \\
\hline Pidlisivka & $\begin{array}{l}\text { Feature 1a } \\
\text { Skeleton } 2\end{array}$ & $\begin{array}{l}\text { Adultus/maturus } \\
\text { (30-40 years) }\end{array}$ & Male & Not done & $\mathrm{YC}$ \\
\hline Pidlisivka & Feature $1 b$ & $\begin{array}{l}\text { Adultus } \\
\text { (22-25 years) }\end{array}$ & Male & $X Y$ & Eneolithic \\
\hline Pidlisivka & Feature 4 & $\begin{array}{l}\text { Infans II } \\
\text { (11-12 years) }\end{array}$ & --- & Not done & $\mathrm{CC}$ \\
\hline Pidlisivka & Feature 5 & $\begin{array}{l}\text { Adultus } \\
\text { (30-35 years) }\end{array}$ & Male & Not done & $\mathrm{BC}$ \\
\hline Pidlisivka & Feature 7 & $\begin{array}{l}\text { Adultus } \\
\text { (25-30 years) }\end{array}$ & Male? & Not done & $\mathrm{CC}$ \\
\hline Pidlisivka & Feature 8 & $\begin{array}{l}\text { Infans I } \\
\text { (1-6 years) }\end{array}$ & --- & Not done & $?$ \\
\hline Pidlisivka & Feature 9 & $\begin{array}{l}\text { Infans I } \\
\text { (0-1 year) }\end{array}$ & --- & Not done & $\mathrm{YC}$ \\
\hline Pidlisivka & Feature 10 & $\begin{array}{l}\text { Infans I } \\
\text { (0-9 months) }\end{array}$ & --- & Not done & Eneolithic \\
\hline Pidlisivka & Feature 11 & $\begin{array}{l}\text { Maturus } \\
\text { (35-40 years) }\end{array}$ & Male & Not done & $\mathrm{YC}$ \\
\hline Pidlisivka & Feature 12 & $\begin{array}{l}\text { Maturus } \\
\text { (50-55 years) }\end{array}$ & Male & Not done & Iron Age \\
\hline Pidlisivka & Feature 13 & $\begin{array}{l}\text { Adultus } \\
\text { (20-25 years) }\end{array}$ & Female? & $\mathrm{XX}$ & $\mathrm{BC}$ \\
\hline
\end{tabular}


From the Porohy site, skeletal material belonging to 20 individuals were recovered: 15 adults and 5 children (Tab. 3) [Klochko et al. 2015b].

\subsubsection{ENEOLITHIC BURIALS}

\section{Barrow 3A, feature 14}

Individual 1 . Bones found in the feature fill were very poorly preserved. They included a few fragments of the cranial vault. The skeleton belonged to a child. Due to the poor state of bone preservation, it was not possible to determine the exact age of the individual. No palaeopathological lesions were observed.

\section{Barrow 3A, feature 14}

Individual 2 . Bones found in the feature fill were very poorly preserved. They included a few fragments of the skull, a fragment of the ulna and another of the fibula, and a fragment of the sacrum, as well as foot phalanges. The skeleton belonged to an adult. Due to the poor state of bone preservation, it was not possible to reconstruct the individual's stature nor estimate his or her age-at-death nor determine sex. No palaeopathological lesions were observed.

Barrow 3A, feature 18

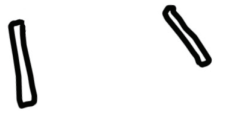

A very poorly-preserved skeleton: only small fragments of long bones were recovered. The skeleton most probably belonged to a child aged 0-7 years (infans I). No palaeopathological lesions were observed.

\subsubsection{YAMNAYA CULTURE BURIALS}

\section{Barrow 3A, feature 1}

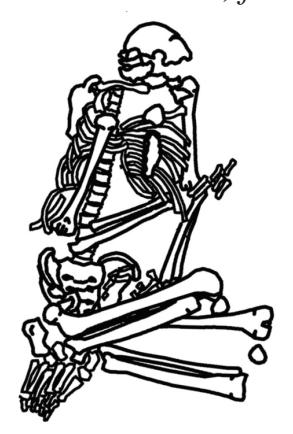

A poorly-preserved skeleton with a badly damaged skull. The preserved bones include very small fragments of the skull, upper and lower limbs, pelvis and foot. The skeleton belonged to a male aged 30-35 years (adultus). Due to the poor state of preservation of long bones, it was not possible to reconstruct his stature.

Palaeopathological lesions: dental calculus and lowering of alveolar processes. The frontal bone bears traces of a compression fracture (located in the middle of the bone) and three 
perforations (one located on the right side, two on the left), showing no traces of obliteration (healing). These can be traces of a ritual skull 'division'. Traces of artificial bone working can be also seen on the fragments of the parietal bones, occipital bone and the mandible; degenerative lesions were observed on vertebrae and phalanges.

\section{Barrow 3A, feature 2}

(2)

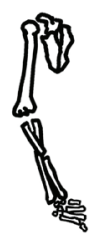

A very poorly-preserved skeleton with a badly damaged skull. The preserved bones include small fragments of the cranial vault, humerus, radius and ulna. The skeleton most probably belonged to a male aged 35-55 years (maturus). Due to the poor state of preservation of long bones, it was not possible to reconstruct his stature. No palaeopathological lesions were observed.

Barrow 3A, feature 10

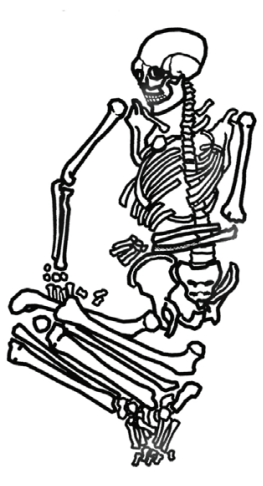

A very poorly-preserved skeleton with a badly damaged skull. The preserved bones include small fragments of the cranial vault and mandible and larger ones of the upper and lower limbs, pelvis fragments and vertebrae. The skeleton belonged to a female aged 25-30 years (adultus). Due to the poor state of preservation of long bones, it was not possible to reconstruct her stature.

Palaeopathological lesions: LEH on both lower canines (age of the individual at the time of both defects: 4.5-5.0 years); caries on the upper left third molar.

\section{Barrow 3A, feature 11}

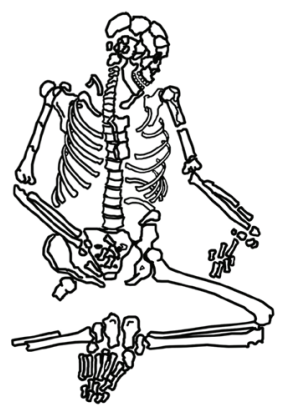

A poorly-preserved skeleton with a badly damaged skull. The preserved bones include small fragments of the skull, upper and lower limbs, small fragments of the pelvis. The skeleton belonged to a male aged 25-30 years (adultus). Due to the poor state of preservation of long bones, it was not possible to reconstruct his stature.

Palaeopathological lesions: dental calculus; amidst pelvis fragments, a flint arrow point was found, but due to the poor state of bone preservation, it is not possible to determine its original location. 
Barrow 3A, feature 12

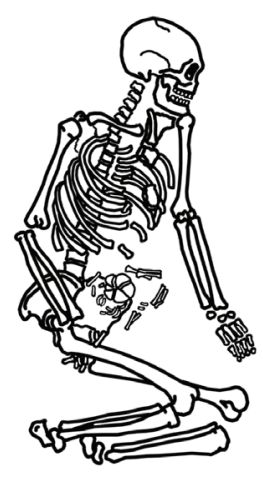

Skeleton 1. A poorly-preserved skeleton with a badly damaged skull. The preserved bones include fragments of the cranial vault, large fragments of upper limb bones (epiphyses are damaged), small fragments of the pelvis, and foot bones. The skeleton belonged to a female aged 22-25 years (adultus). The molecular analysis corroborated the morphological sex assessment. The stature of the individual was approx. $160 \mathrm{~cm}$.

Palaeopathological lesions: porotic hyperostosis (1st degree according to GHHP) of the right parietal bone; dental calculus.

Skeleton 2. A well-preserved skeleton with a badly damaged skull. The preserved bones include small fragments of the skull, upper and lower limbs, pelvis, vertebrae and ribs. The skeleton belonged to a child (foetus). No palaeopathological lesions were observed.

Barrow 3A, feature 15

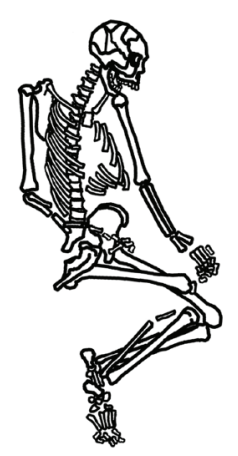

A poorly-preserved skeleton with a badly damaged skull. The preserved bones include small fragments of the skull, upper and lower limbs, and vertebrae. The skeleton belonged to a male aged 25-30 years (adultus). Due to the poor state of preservation of long bones, it was not possible to reconstruct his stature.

Palaeopathological lesions: degenerative lesions on the proximal ends of metatarsal bones and two phalanges.

\section{Barrow 3A, feature 17}

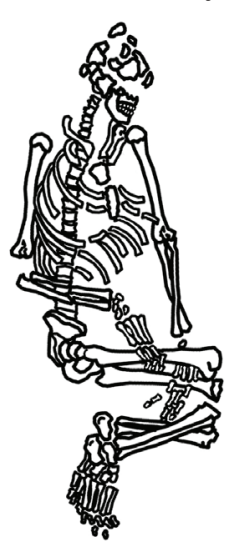

A poorly-preserved skeleton with a badly damaged skull. The preserved bones include small fragments of the skull, upper and lower limb bones (epiphyses are partly damaged) and small fragments of the pelvis and vertebrae. The skeleton belonged to a male aged 30-35 years (adultus). Due to the poor state of preservation of long bones, it was not possible to reconstruct his stature.

Palaeopathological lesions: osteophytes on the olecranon of the right ulna; degenerative lesions on cervical vertebrae. 
Barrow 3A, feature 19

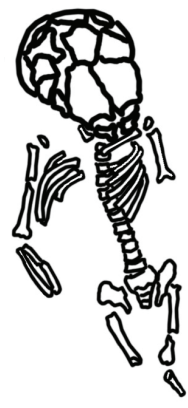

A poorly-preserved skeleton with a badly damaged skull. The preserved bones include very small fragments of the skull, upper and lower limb bones, pelvis and vertebrae. The skeleton belonged to a child aged 0-18 months (infans I).

Palaeopathological lesions: caries of the upper right second deciduous molar; cribra orbitalia (1st degree according to GHHP, type: healed) on the right orbital roof.

Barrow $3 A$, feature 20

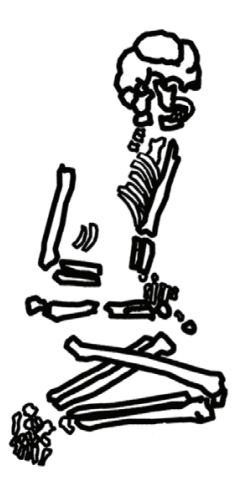

Skeleton 1. A very poorly-preserved skeleton with a badly damaged skull. The preserved bones include small fragments of the skull and lower limbs. The skeleton belonged to a male aged 50-55 years (maturus). Due to the poor state of preservation of long bones, it was not possible to reconstruct stature. No palaeopathological lesions were observed.

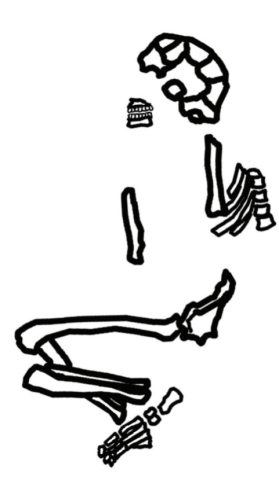

Skeleton 2. A very poorly-preserved skeleton with a badly damaged skull. The preserved bones include small fragments of the skull and lower limbs. The skeleton belonged to an adult aged 20-55 years (adultus/maturus). Due to the poor state of bone preservation, it was not possible to reconstruct the individual's stature. The results of molecular analysis implied this individual to be female. No palaeopathological lesions were observed. 
Barrow 3A, feature 5

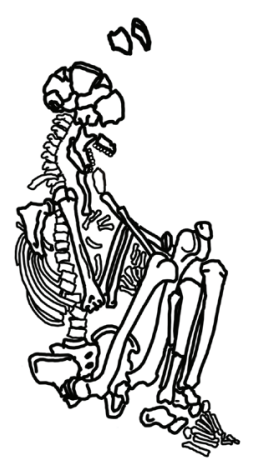

A very poorly-preserved skeleton with a badly damaged skull. The preserved bones include small fragments of the skull, upper and lower limbs, pelvis fragments, vertebrae and foot bones. The skeleton belonged to a male aged 25-30 years (adultus). The stature of the individual was approx. $178 \mathrm{~cm}$. No palaeopathological lesions were observed.

Barrow 3, feature 8

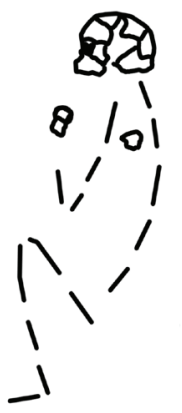

A poorly-preserved skeleton with a badly damaged skull. The preserved bones include small fragments of the skull and lower and upper limbs, as well as small fragments of the pelvis. The skeleton belonged to a male aged 20-55 years (adultus/maturus). Due to the poor state of preservation of long bones, it was not possible to reconstruct his stature. No palaeopathological lesions were observed.

Barrow 3A, feature 22

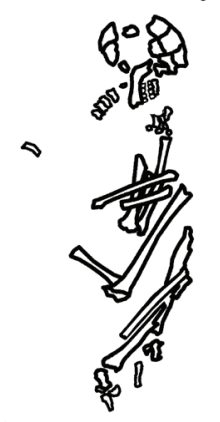

A poorly-preserved skeleton with a badly damaged skull. The preserved bones include small fragments of the cranial vault, mandible fragments, small fragments of upper and lower limb bones. The skeleton belonged to a male aged 30-35 years (adultus). Due to the poor state of preservation of long bones, it was not possible to reconstruct his stature. No palaeopathological lesions were observed. 
Barrow 3A, feature 3

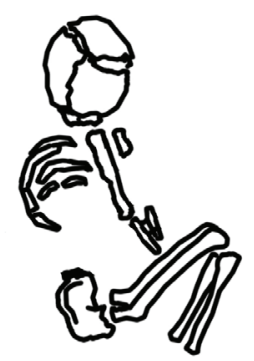

A very poorly-preserved skeleton with a badly damaged skull. The preserved bones include small fragments of the skull and of long bones. The skeleton belonged to a child aged 0-3 years (infans I). No palaeopathological lesions were observed.

Barrow 3A, feature 7

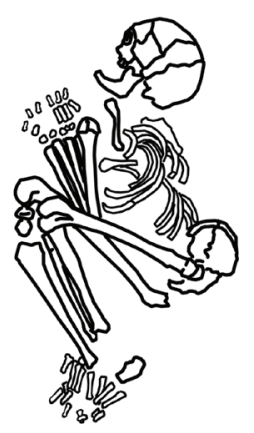

A very poorly-preserved skeleton with a badly damaged skull. The preserved bones include small fragments of the cranial vault, pelvis and fragments of long bones. The skeleton most probably belonged to a male aged $35-55$ years (maturus). Due to the poor state of preservation of long bones, it was not possible to reconstruct his stature.

Palaeopathological lesions: degenerative lesions were observed on vertebrae and phalanges.

3.2.4. IRON AGE BURIAL

Barrow 3A, feature 21

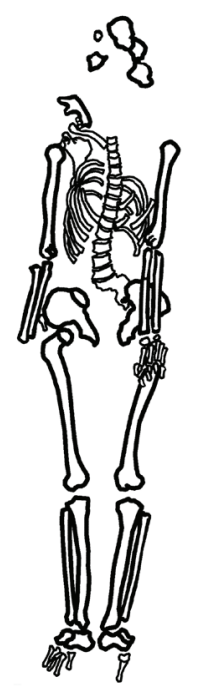

A poorly-preserved skeleton with a badly damaged skull. The preserved bones include small fragments of the skull and lower and upper limbs, as well as small fragments of the pelvis and vertebrae. The skeleton belonged to a female aged 45-50 years (maturus). Due to the poor state of preservation of long bones, it was not possible to reconstruct her stature.

Palaeopathological lesions: degenerative lesions on vertebrae. 
$\mathrm{T} a \mathrm{~b} \mid \mathrm{e} \quad 3$

Basic information on skeletal material from Barrow 3A, Porohy site

\begin{tabular}{|c|c|c|c|c|c|}
\hline Site & Grave & $\begin{array}{l}\text { Anthropological } \\
\text { Age } \\
\text { Determination }\end{array}$ & $\begin{array}{l}\text { Anthropo- } \\
\text { logical Sex } \\
\text { Assignment }\end{array}$ & $\begin{array}{l}\text { Molecular } \\
\text { Sex } \\
\text { Assignment }\end{array}$ & $\begin{array}{l}\text { Archaeological } \\
\text { Culture }\end{array}$ \\
\hline Porohy $3 \mathrm{~A}$ & Feature 1 & $\begin{array}{l}\text { Adultus } \\
\text { (30-35 years) }\end{array}$ & Male & Not done & $\mathrm{YC}$ \\
\hline Porohy $3 \mathrm{~A}$ & Feature 2 & $\begin{array}{l}\text { Maturus } \\
\text { (35-55 years) }\end{array}$ & Male? & Not done & $\mathrm{YC}$ \\
\hline Porohy $3 \mathrm{~A}$ & Feature 3 & $\begin{array}{l}\text { Infans } I \\
\text { (0-3 years) }\end{array}$ & --- & Not done & $\mathrm{NC}$ \\
\hline Porohy $3 \mathrm{~A}$ & Feature 5 & $\begin{array}{l}\text { Adultus } \\
\text { (25-30 years) }\end{array}$ & Male & Not done & $\mathrm{NC}$ \\
\hline Porohy 3A & Feature 7 & $\begin{array}{l}\text { Maturus } \\
\text { (35-55 years) }\end{array}$ & Male? & Not done & $\mathrm{NC}$ \\
\hline Porohy $3 \mathrm{~A}$ & Feature 8 & $\begin{array}{l}\text { Adultus/maturus } \\
\text { (20-55 years) }\end{array}$ & Male & Not done & $\mathrm{NC}$ \\
\hline Porohy $3 \mathrm{~A}$ & Feature 10 & $\begin{array}{l}\text { Adultus } \\
\text { (25-30 years) }\end{array}$ & Female & Not done & $\mathrm{YC}$ \\
\hline Porohy $3 \mathrm{~A}$ & Feature 11 & $\begin{array}{l}\text { Adultus } \\
\text { (25-30 years) }\end{array}$ & Male & Not done & $\mathrm{YC}$ \\
\hline Porohy $3 \mathrm{~A}$ & $\begin{array}{l}\text { Feature } 12 \\
\text { skeleton } 1\end{array}$ & $\begin{array}{l}\text { Adultus } \\
\text { (22-25 years) }\end{array}$ & Female & XX & $\mathrm{YC}$ \\
\hline Porohy $3 \mathrm{~A}$ & $\begin{array}{l}\text { Feature } 12 \\
\text { skeleton } 2\end{array}$ & $\begin{array}{l}\text { Child } \\
\text { (Foetus) }\end{array}$ & --- & Not done & $\mathrm{YC}$ \\
\hline Porohy $3 \mathrm{~A}$ & Feature 14 & $\begin{array}{l}\text { Child } \\
\text { (below } 20 \text { years) }\end{array}$ & --- & Not done & Eneolithic \\
\hline Porohy $3 \mathrm{~A}$ & Feature 14 & $\begin{array}{l}\text { Adult } \\
\text { (above } 20 \text { years) }\end{array}$ & $?$ & Not done & Eneolithic \\
\hline Porohy $3 \mathrm{~A}$ & Feature 15 & $\begin{array}{l}\text { Adultus } \\
(25-30)\end{array}$ & Male & Not done & $\mathrm{YC}$ \\
\hline Porohy $3 \mathrm{~A}$ & Feature 17 & $\begin{array}{l}\text { Adultus } \\
(30-35)\end{array}$ & Male & Not done & $\mathrm{YC}$ \\
\hline Porohy $3 \mathrm{~A}$ & Feature 18 & $\begin{array}{l}\text { Infans I } \\
(0-7 \text { years })\end{array}$ & --- & Not done & Eneolithic \\
\hline Porohy $3 \mathrm{~A}$ & Feature 19 & $\begin{array}{l}\text { Infans I } \\
\text { (0-18 months) }\end{array}$ & --- & Not done & $\mathrm{YC}$ \\
\hline Porohy 3A & $\begin{array}{l}\text { Feature } 20 \\
\text { skeleton } 1\end{array}$ & $\begin{array}{l}\text { Maturus } \\
\text { (50-55 years) }\end{array}$ & Male & Not done & $\mathrm{YC}$ \\
\hline Porohy $3 \mathrm{~A}$ & $\begin{array}{l}\text { Feature } 20 \\
\text { skeleton } 2\end{array}$ & $\begin{array}{l}\text { Adultus/maturus } \\
\text { (20-55 years) }\end{array}$ & $?$ & $\mathrm{XX}$ & $\mathrm{YC}$ \\
\hline Porohy $3 \mathrm{~A}$ & Feature 21 & $\begin{array}{l}\text { Maturus } \\
\text { (45-50 years) }\end{array}$ & Female & Not done & Iron Age \\
\hline Porohy $3 \mathrm{~A}$ & Feature 22 & $\begin{array}{l}\text { Adultus } \\
\text { (30-35 years) }\end{array}$ & Male & Not done & $\mathrm{NC}$ \\
\hline
\end{tabular}


From the Klembivka 1 site, skeletal material belonging to 11 individuals were recovered: ${ }^{2}$ eight adults and three children (Tab. 4) [Klochko et al. 2015c].

\subsubsection{ENEOLITHIC BURIALS}

\section{Barrow 1, feature 5}

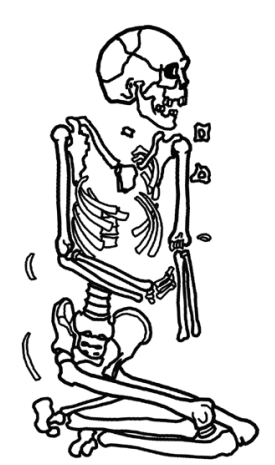

A poorly-preserved skeleton with a badly damaged skull. The preserved bones include small fragments of the skull and large fragments of upper and lower limb bones. The skeleton belonged to a male aged 50-55 years (maturus). Due to the poor state of preservation of long bones, it was not possible to reconstruct his stature.

Palaeopathological lesions: caries of both upper first molars, second upper left premolar, upper right second molar, both lower first molars, second left lower molar, both lower third molars; both lower first molars were lost antemortem; bilateral maxillary sinusitis; extreme lowering of alveolar processes; ossified ligaments on the right patella (enthesopathy); osteophytes on lumbar vertebrae; degenerative lesions on the right acetabulum of the hip joint and the odontoid process.

\section{Barrow 1, feature 14}

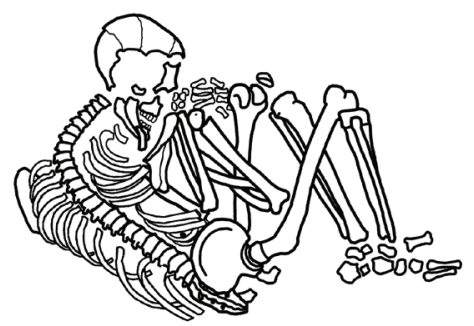

A poorly-preserved skeleton with a badly damaged skull. The preserved bones include small fragments of the skull, fragments of upper and lower limb bones, small fragments of the pelvis. The skeleton belonged to a male aged 25-30 years (adultus). Due to the poor state of preservation of long bones, it was not possible to reconstruct his stature.

Palaeopathological lesions: caries of the upper right first molar, upper left third molar, both lower second molars, both lower molars, lower right molar; porotic hyperostosis (1st degree according to GHHP) of the right parietal bone; dental calculus and lowering of alveolar processes; degenerative lesions of the proximal end of a hand phalanx.

\footnotetext{
2 The anthropological report, due to the destruction of materials, ignored the remains of presumably, a child discovered on the Klembivka site within feature 6 .
} 
Barrow 1, feature 15

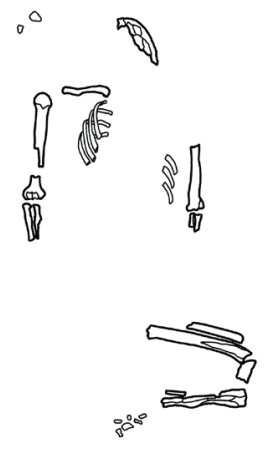

A poorly-preserved skeleton with a badly damaged skull. The preserved bones include small fragments of the cranial vault and fragments of upper and lower limb bones. The skeleton belonged to child aged 15-20 years (juvenis). No palaeopathological lesions were observed.

3.3.2. BABYNO CULTURE BURIALS

Barrow 1, feature 2

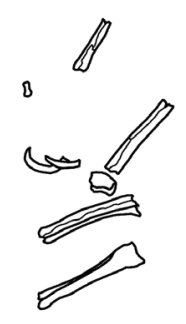

$ه$

A poorly-preserved skeleton. The preserved bones include small fragments of lower limb bones. The skeleton belonged to an adult individual. Due to the poor state of bone preservation, it was not possible to reconstruct the individual's stature nor estimate his or her age-at-death nor determine sex. No palaeopathological lesions were observed.

Barrow 1, feature 3

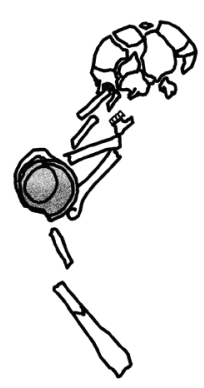

A poorly-preserved skeleton with a badly damaged skull. The preserved bones include fragments of the skull and lower limbs. The skeleton most probably belonged to a male aged 35-45 years (maturus). Due to the poor state of preservation of long bones, it was not possible to reconstruct his stature. No palaeopathological lesions were observed. 


\section{Barrow 1, feature 7}
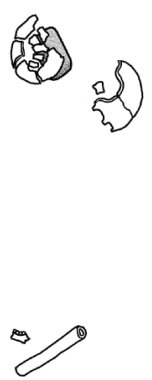

The pit fill contained the human skeletal remains of three individuals.

Skeleton 1. A poorly-preserved skeleton with a badly damaged skull. The preserved bones include small fragments of the cranial vault and two fragments of the femur. The skeleton belonged to a male aged 35-55 years (maturus). Due to the poor state of preservation of long bones, it was not possible to reconstruct his stature. No palaeopathological lesions were observed.

Skeleton 2. A poorly-preserved skeleton with a badly damaged skull. The preserved bones include small fragments of the skull and upper and lower limbs. The skeleton belonged to a child aged 4-5 years (infans I). No palaeopathological lesions were observed.

Skeleton 3. A poorly-preserved skeleton with a badly damaged skull. The preserved bones include large fragments of lower limbs. The skeleton most probably belonged to a female aged 35-55 years (maturus). Due to the poor state of preservation of long bones, it was not possible to reconstruct her stature.

Palaeopathological lesions: extreme lowering of alveolar processes.

Barrow 1, feature 11

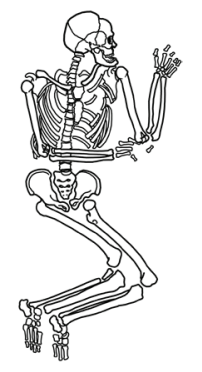

A well-preserved skeleton with a badly damaged skull. The preserved bones include small fragments of the skull, upper and lower limbs, the pelvis and a foot. The skeleton belonged to a male aged 20-25 years (adultus). The molecular analysis not corroborated the morphological sex assessment. The stature of the individual was approx. $174 \mathrm{~cm}$.

Palaeopathological lesions: dental calculus, Schmorl's nodes on thoracic vertebrae, degenerative lesions of the proximal end of the 1 st metatarsal bone.

\section{Barrow 1, feature 12}

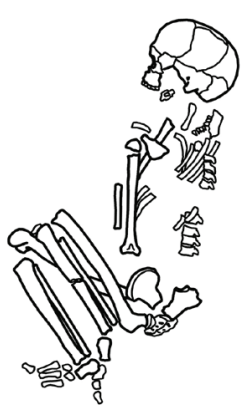

A very poorly-preserved skeleton with a badly damaged skull. The preserved bones include small fragments of the skull and upper and lower limbs, as well as small fragments of the pelvis. The skeleton belonged to a child aged 12-14 years (infans II). The results of molecular analysis implied this individual to be female.

Palaeopathological lesions: LEH on the upper right second premolar (age of the individual at the time of defect: 4.5-5.0 years). 
Barrow 1, feature 13

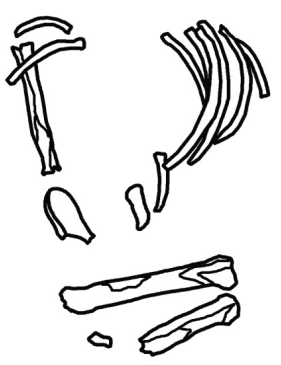

A very poorly-preserved skeleton: only small fragments of long bones (femur and tibia) were recorded. The skeleton belonged to an adult. Due to the poor state of bone preservation, it was not possible to reconstruct the individual's stature nor estimate his or her age nor determine sex. No palaeopathological lesions were observed.

Ta b I e 4

Basic information on skeletal material from Barrow 1, Klembivka site

\begin{tabular}{|l|l|l|l|l|l|}
\hline Site & Grave & $\begin{array}{l}\text { Anthropological } \\
\text { Age } \\
\text { Determination }\end{array}$ & $\begin{array}{l}\text { Anthropo- } \\
\text { logical Sex } \\
\text { Assignment }\end{array}$ & $\begin{array}{l}\text { Molecular } \\
\text { Sex } \\
\text { Assignment }\end{array}$ & $\begin{array}{l}\text { Archaeological } \\
\text { Culture }\end{array}$ \\
\hline Klembivka 1 & Feature 2 & $\begin{array}{l}\text { Adult } \\
\text { (20+ years })\end{array}$ & $?$ & Not done & BC \\
\hline Klembivka 1 & Feature 3 & $\begin{array}{l}\text { Maturus } \\
\text { (35-45 years })\end{array}$ & Male & Not done & BC \\
\hline Klembivka 1 & Feature 5 & $\begin{array}{l}\text { Maturus } \\
(50-55 \text { years })\end{array}$ & Male & Not done & Eneolithic \\
\hline Klembivka 1 & $\begin{array}{l}\text { Feature 7 } \\
\text { skeleton 1 }\end{array}$ & $\begin{array}{l}\text { Maturus } \\
(35-55 \text { years })\end{array}$ & Male & Not done & NC \\
\hline Klembivka 1 & $\begin{array}{l}\text { Feature 7 } \\
\text { skeleton 2 }\end{array}$ & $\begin{array}{l}\text { Infans I } \\
(4-5 \text { years })\end{array}$ & --- & Not done & NC \\
\hline Klembivka 1 & $\begin{array}{l}\text { Feature 7 } \\
\text { skeleton 3 }\end{array}$ & $\begin{array}{l}\text { Adultus } \text { maturus } \\
20-55 \text { years })\end{array}$ & Female? & Not done & NC \\
\hline Klembivka 1 & Feature 11 & $\begin{array}{l}\text { Adultus } \\
(20-25 \text { years })\end{array}$ & Male & XX & NC \\
\hline Klembivka 1 & Feature 12 & $\begin{array}{l}\text { Infans II } \\
(12-14 \text { years })\end{array}$ & --- & XX & NC \\
\hline Klembivka 1 & Feature 13 & $\begin{array}{l}\text { Adult } \\
(+20 \text { years })\end{array}$ & $?$ & Not done & NC \\
\hline Klembivka 1 & Feature 14 & $\begin{array}{l}\text { Adultus } \\
(25-30 \text { years })\end{array}$ & Male & Not done & Eneolithic \\
\hline Klembivka 1 & Feature 15 & $\begin{array}{l}\text { Juvenis } \\
(15-20 \text { years })\end{array}$ & --- & Not done & Eneolithic \\
\hline
\end{tabular}


3.4. PRYDNISTRYANSKE 1

From the Prydnistryanske site 1 , skeletal material belonging to 17 individuals were recovered: 14 adults and 3 children (Tab. 5) [Klochko et al 2015].

3.4.1. BARROW I

\subsubsection{CATACOMB CULTURE BURIALS}

Feature I/4, skeleton 1

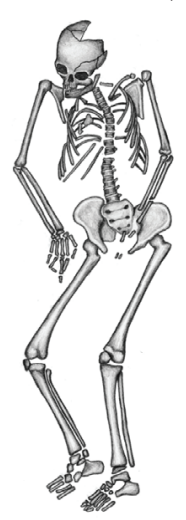

A poorly-preserved skeleton with a badly damaged skull. The following skull bones or their fragments were preserved: frontal bone, occipital bone, sphenoid bone, mandible, parietal bones, temporal bones, zygomatic bones, maxillary bones. The postcranial skeleton was represented by the following bones or their fragments: clavicles, scapulae, patellae, sternum, ilia , ischia, pubis, sacrum, vertebrae, ribs, humeri, ulnae, radii, femora, tibiae, fibulae, hand and foot bones. The skeleton belonged to an adolescent aged about 15 years $(j u-$ venis). The results of molecular analysis implied this individual to be male.

Palaeopathological lesions: LEH on both lower medial incisors (age of the individual at the time of both defects: 2.0-2.5 years).

Feature I/4, skeleton 2

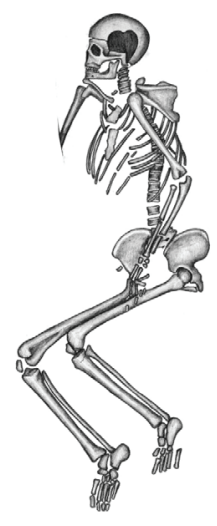

A well-preserved skeleton with a badly damaged skull. The following skull bones or their fragments were preserved: frontal bone, occipital bone, sphenoid bone, mandible, parietal bones, temporal bones, zygomatic bones, maxillary bones and left palatine bone. The postcranial skeleton was represented by the following bones or their fragments: clavicles, scapulae, patellae, sternum, ilia, ischia, pubis, sacrum, vertebrae, ribs, humeri, ulnae, radii, femora, tibiae, fibulae, hand and foot bones. The skeleton most probably belonged to a male aged 35-50 years (maturus).The results of molecular analysis implied this individual to be female. The stature of the individual was approx. $165 \mathrm{~cm}$.

Palaeopathological lesions: osteophytes on three lumbar vertebrae; ossified ligaments on both patellae and both calcanei (enthesopathy). 


\subsubsection{IRON AGE BURIALS}

\section{Feature I/2}

A very poorly-preserved skeleton. The following bones or their fragments were recorded: right maxilla, left zygomatic bone, vertebrae, right ilium, right femur. The skeleton belonged to a child aged about 4 years (infans I). No palaeopathological lesions were observed.

\section{Feature I/3}

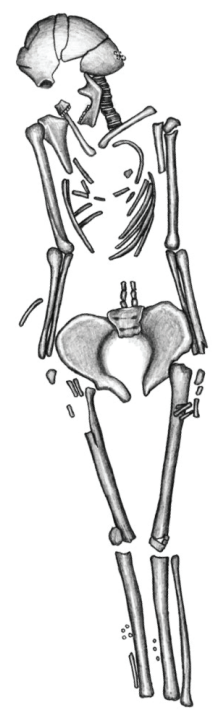

畋:

A poorly-preserved skeleton with a badly damaged skull. The following skull bones or their fragments were preserved: frontal bone, occipital bone, sphenoid bone, mandible, both parietal bones, temporal bones, right zygomatic bone, maxillary bones, right palatine bone. The postcranial skeleton was represented by the following bones or their fragments: clavicles, scapulae, patellae, ilia, ischia, pubis, sacrum, vertebrae, ribs, humeri, ulnae, radii, femora, tibiae, fibulae, hand and foot bones. The skeleton belonged to a female aged 45-55 years (maturus). The stature of the individual was approx. $162 \mathrm{~cm}$.

Palaeopathological lesions: degenerative lesions of the spinal column (spondylosis) observable on three cervical vertebrae (C3-5); caries of the right upper first molar, lower left first molar, lower left second molar; upper right second molar, upper left second premolar, upper left first molar, upper left second molar, lower right second premolar were lost antemortem.

3.4.2. BARROW II

\subsubsection{ENEOLITHIC BURIAL}

\section{Feature II/1}

A very poorly-preserved skeleton. The following bones or their fragments were recorded: a vertebra, metacarpals, and ilium. The skeleton must have belonged to an adult. Due to the poor state of bone preservation, it was not possible to reconstruct the individual's stature nor estimate his or her age-at-death nor determine sex. No palaeopathological lesions were observed. 


\subsubsection{BURIAL OF AN INDETERMINATE CHRONOLOGY}

\section{Feature II/3}

A very poorly-preserved skeleton. Only very fine fragments of human bones were recorded. The skeleton must have belonged to an adult. Due to the poor state of bone preservation, it was not possible to reconstruct the individual's stature nor estimate his or her age-at-death nor determine sex. No palaeopathological lesions were observed.

\subsubsection{BARROW III}

\subsubsection{ENEOLITHIC BURIALS}

Feature III/1

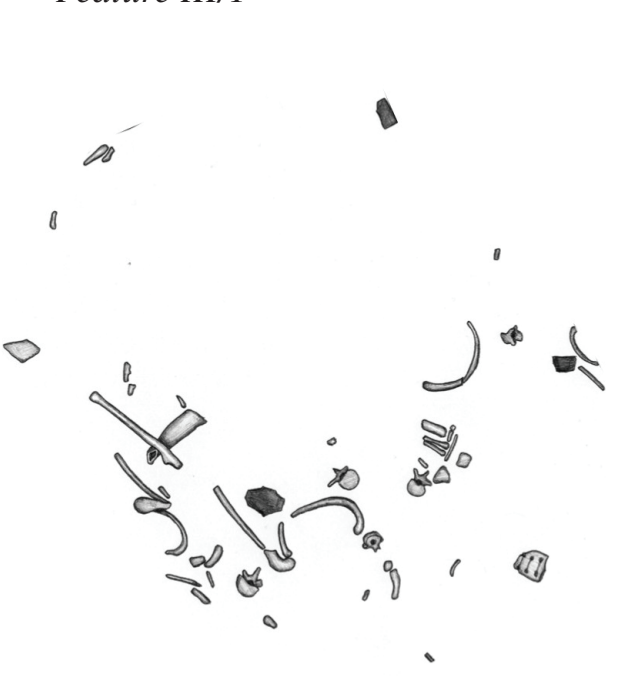

Feature III/2

A very poorly-preserved skeleton. The following bones or their fragments were recorded: the sternum, ribs, scapulae, vertebrae, ulnae, femora, left ischium, left pubic bone, sacrum, carpal bones, tarsals, metacarpals, metatarsals, phalanges. The skeleton belonged to an adult. Due to the poor state of bone preservation, it was not possible to reconstruct the individual's stature nor estimate his or her age-at-death nor determine sex.

Palaeopathological lesions: healed fracture of the left ulna; block of two thoracic vertebrae, osteophytes on cervical and thoracic vertebrae.

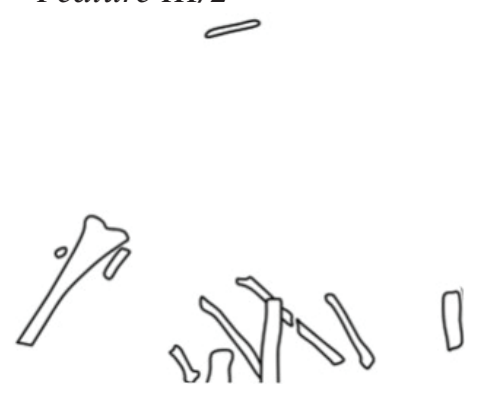

Very poorly-preserved skeletal material. The following bones or their fragments were recorded: the sternum, ribs, scapula, vertebrae, femora, fibulae, tibia, right patella, carpals, metacarpals, tarsals, metatarsals, phalanges. The skeletal material belonged to two individuals: a child aged 9-10 years (infans II) and an adult. Due to the poor state of bone preservation, it 
was not possible to reconstruct the adult individual's stature nor estimate his or her age nor determine sex. No palaeopathological lesions were observed.

\section{Feature III/3}

Very poorly-preserved skeletal material. Only a small fragment of a human bone, belonging to an adult, was recorded. Due to the poor state of bone preservation, it was not possible to reconstruct the individual's stature nor estimate his or her age-at-death nor determine sex. No palaeopathological lesions were observed.

\subsubsection{IRON AGE BURIAL}

\section{Feature III/4}

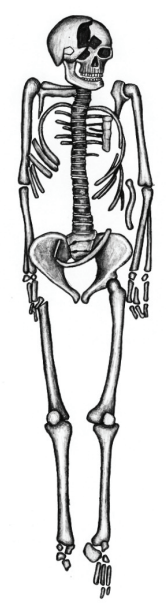

A poorly-preserved skeleton with a badly damaged skull. The following skull bones or their fragments were preserved: frontal bone, occipital bone, sphenoid bone, mandible, parietal bones, temporal bones, left zygomatic bone, maxillary bones, left palatine bone. The postcranial skeleton was represented by the following bones or their fragments: clavicles, scapulae, patellae, sternum, ilia, ischia, pubic bones, sacrum, vertebrae, ribs, humeri, right ulna, radii, femora, tibiae, fibulae, hand and foot bones. The skeleton belonged to a male aged 30-40 years (adultus/maturus). The stature of the individual was approx. $169 \mathrm{~cm}$.

Palaeopathological lesions: caries of the upper right third molar, lower right second molar, lower right first molar and lower left first molar; telltale wearing of the tooth crowns due to occupational stress of the upper right second premolar (distal surface) and upper right first molar (mesial surface); lower left second molar and lower left third molar were lost antemortem; osteophytes were recorded on two thoracic (Th9-10) and two lumbar (L4-5) vertebrae.

3.4.4. BARROW IV

3.4.4.1. ENEOLITHIC BURIAL

\section{Feature IV/10}

A very poorly-preserved skeleton of an adult. The following bones or their fragments were recorded: skull bones, a rib, vertebra, carpals, tarsals, metatarals, phalanges. Due to the poor state of bone preservation, it was not possible to recon- 
struct the individual's stature nor estimate his or her age-at-death nor determine sex. No palaeopathological lesions were observed.

\subsubsection{YAMNAYA CULTURE}

\section{Feature IV/3}

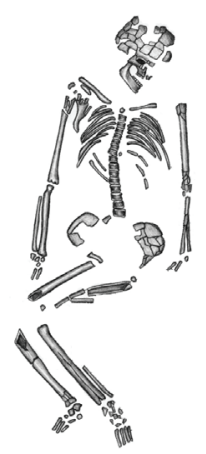

Feature IV/4

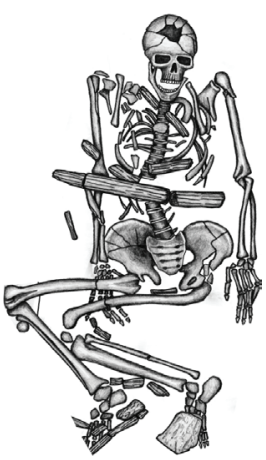

A very poorly-preserved skeleton with a badly damaged skull. The following skull bones or their fragments were preserved: frontal bone, occipital bone, mandible, parietal bones, temporal bones. The postcranial skeleton was represented by the following bones or their fragments: scapulae, patellae, ilia, pubic bones, sacrum, vertebrae, ribs, humeri, right radius, right ulna, femora, tibiae, fibulae, hand and foot bones. The skeleton belonged to an adult aged over 40 years (maturus/ senilis). Due to the poor state of bone preservation, it was not possible to reconstruct the individual's stature nor determine his or her sex. No palaeopathological lesions were observed.

A well-preserved skeleton with a badly damaged skull. The following skull bones or their fragments were preserved: frontal bone, occipital bone, sphenoid bone, mandible, parietal bones, temporal bones, zygomatic bones, and maxillae. The postcranial skeleton was represented by the following bones or their fragments: clavicles, right scapula, patellae, sternum, ilia, ischia, pubic bones, sacrum, vertebrae, ribs, humeri, ulnae, radii, femur, tibiae, fibulae, hand and foot bones. The skeleton belonged to a male aged 35-50 years (maturus). The molecular analysis corroborated the morphological sex assessment. The stature of the individual was approx. $187 \mathrm{~cm}$.

Palaeopathological lesions: osteoarthritis of the left carpals (scaphoid, lunate, triquetrum, capitate, trapezoid, hamate), sternal ends of the left and right clavicle, right clavicular notch of the manubrium sterni, articular surfaces of both scapulae, head of the left humerus, articular surface of the distal end of the left radius, articular surface of the distal end of the right ulna and articular surface of the distal end of the right radius. These lesions are related to the individual's great physical activity and the mechanical stress he must have been subjected to [Molnar et al. 2011; Weiss, Jurmain 2007]. Other lesions include: blocks of cervical vertebrae (C1-2 and C3-4), spondylosis of two cervical and five thoracic vertebrae, and of the fifth lumbar vertebra (L-5) and the base of the sacrum; Schmorl's nodes on the first thoracic vertebra; osteophytes on three lumbar vertebrae; ossified ligaments (enthesopathy) on the right calcaneus. 
Feature IV/6

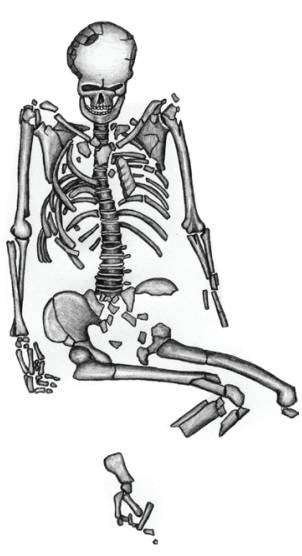

A poorly-preserved skeleton with a badly damaged skull. The following skull bones or their fragments were preserved: frontal bone, occipital bone, sphenoid bone, mandible, parietal bones, temporal bones, zygomatic bones, maxillary bones. The postcranial skeleton was represented by the following bones or their fragments: clavicles, scapulae, patellae, sternum, ilia, left ischium, pubic bones, vertebrae, ribs, humeri, ulnae, radii, femora, tibiae, right fibula, hand and foot bones. The skeleton belonged to a male aged above 45 years (maturus/senilis). Due to the poor state of preservation of long bones, it was not possible to reconstruct his stature.

Palaeopathological lesions: lower left medial incisor was lost antemortem; telltale wearing of the tooth crowns, due to occupational stress, of the upper right third molar (mesial surface), upper right second molar (distal surface), upper right first molar (mesial and distal surfaces), upper right second premolar (distal surface), upper right first premolar (distal surface), lower left second premolar (distal surface), lower right second premolar (distal surface), lower right first molar (mesial and distal surfaces), lower right second molar (distal surface); osteophytes on three fragments of vertebra bodies; ossified ligaments (enthesopathy) on both patellae.

Feature IV/8

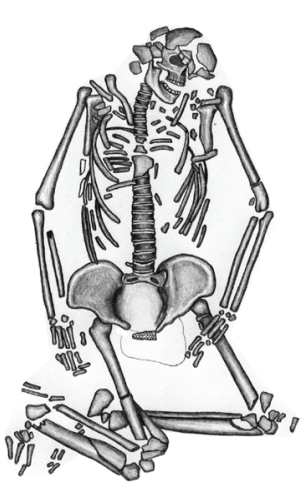

A poorly-preserved skeleton with a badly damaged skull. The following skull bones or their fragments were preserved: frontal bone, occipital bone, sphenoid bone, mandible, parietal bones, temporal bones, zygomatic bones, maxillae. The postcranial skeleton was represented by the following bones or their fragments: clavicles, scapulae, patellae, sternum, ilia, ischia, pubic bones, sacrum, vertebrae, ribs, humeri, ulnae, radii, femora, tibiae, fibulae, hand and foot bones. The skeleton belonged to a male aged 35-50 years (maturus). Due to the poor state of preservation of long bones, it was not possible to reconstruct his stature.

Palaeopathological lesions: Schmorl's nodes on four thoracic vertebrae; cribra orbitalia (1st degree on the GHHP 2006 scale, type: healed) on the right orbital roof; ossified ligaments (enthesopathy) on both patellae. 


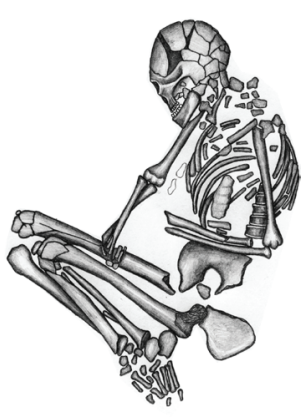

A poorly-preserved skeleton with a badly damaged skull. The following skull bones or their fragments were preserved: frontal bone, occipital bone, sphenoid bone, mandible, parietal bones, temporal bones, right zygomatic bone, maxillary bone. The postcranial skeleton was represented by the following bones or their fragments: clavicles, scapulae, patellae, sternum, ilia, ischia, pubic bones, vertebrae, ribs, humeri, ulnae, radii, femora, tibiae, fibulae, hand and foot bones. The skeleton belonged to a male aged 25-35 years (adultus). The molecular analysis corroborated the morphological sex assessment. Due to the poor state of preservation of long bones, it was not possible to reconstruct his stature.

Palaeopathological lesions: osteoarthritis on the sternal end of the left clavicle. These lesions are related to the individual's great physical activity and the mechanical stress he must have been subjected to [Molnar et al. 2011, Weiss, Jurmain 2007]. Schmorl's nodes were recorded on two vertebrae.

\subsubsection{IRON AGE BURIAL}

\section{Feature IV/I}

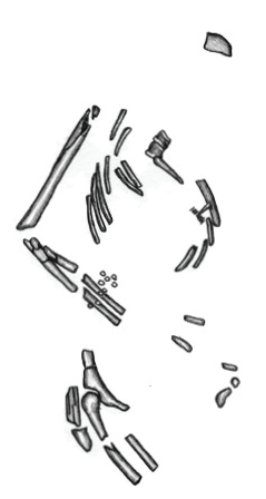

A poorly-preserved skeleton. The following bones or their fragments were recovered: occipital bone, left femur, fibula, hand phalanx, as well numerous fragments of the shafts and epiphyses of long bones. The skeleton belonged to an adult. Due to the poor state of bone preservation, it was not possible to reconstruct the individual's stature nor estimate his or her age-at-death nor determine sex. No palaeopathological lesions were observed.

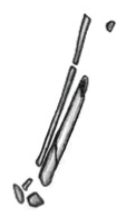


$\mathrm{T} a \mathrm{~b} \mid \mathrm{e} \quad 5$

Basic information on skeletal material from the Prydnistryanske site

\begin{tabular}{|c|c|c|c|c|c|}
\hline Site & Grave & $\begin{array}{l}\text { Anthropological } \\
\text { Age } \\
\text { Determination }\end{array}$ & $\begin{array}{l}\text { Anthropological } \\
\text { Sex } \\
\text { Assignment } \\
\end{array}$ & $\begin{array}{l}\text { Molecular } \\
\text { Sex } \\
\text { Assignment } \\
\end{array}$ & $\begin{array}{l}\text { Archaeological } \\
\text { Culture }\end{array}$ \\
\hline Prydnistryanske 1 & $\mathrm{I} / 2$ & $\begin{array}{l}\text { Infans I } \\
\text { (about } 4 \text { years) }\end{array}$ & --- & Not done & Iron Age \\
\hline Prydnistryanske 1 & $\mathrm{I} / 3$ & $\begin{array}{l}\text { Maturus } \\
\text { (45-55 years) }\end{array}$ & Female & Not done & Iron Age \\
\hline Prydnistryanske 1 & $\mathrm{I} / 4 \mathrm{~S} 1$ & $\begin{array}{l}\text { Juvenis } \\
\text { (14-15 years) }\end{array}$ & --- & $\mathrm{XY}$ & $\mathrm{CC}$ \\
\hline Prydnistryanske 1 & $\mathrm{I} / 4 \mathrm{~S} 2$ & $\begin{array}{l}\text { Maturus } \\
\text { (35-50 years) }\end{array}$ & Male? & $\mathrm{XX}$ & $\mathrm{CC}$ \\
\hline Prydnistryanske 1 & $\mathrm{II} / 3$ & $\begin{array}{l}\text { Adultus } \\
\text { (20+ years) }\end{array}$ & $?$ & Not done & Iron Age \\
\hline Prydnistryanske 1 & III/1 & $\begin{array}{l}\text { Adultus } \\
(20+\text { years })\end{array}$ & $?$ & Not done & Eneolithic \\
\hline Prydnistryanske 1 & $\begin{array}{l}\text { III } \\
/ 2 \mathrm{~S} 1\end{array}$ & $\begin{array}{l}\text { Adultus } \\
(20+\text { years })\end{array}$ & $?$ & Not done & Eneolithic \\
\hline Prydnistryanske 1 & $\mathrm{III} / 2 \mathrm{~S} 2$ & $\begin{array}{l}\text { Infans II } \\
\text { (9-10 years) }\end{array}$ & --- & Not done & Eneolithic \\
\hline Prydnistryanske 1 & $\mathrm{III} / 3$ & $\begin{array}{l}\text { Adultus } \\
(20+\text { years })\end{array}$ & $?$ & Not done & Eneolithic \\
\hline Prydnistryanske 1 & $\mathrm{III} / 4$ & $\begin{array}{l}\text { Adultus/maturus } \\
\text { (30-40 years) }\end{array}$ & Male & Not done & Iron Age \\
\hline Prydnistryanske 1 & $\mathrm{IV} / 1$ & $\begin{array}{l}\text { Adultus } \\
(20+\text { years })\end{array}$ & $?$ & Not done & Iron Age \\
\hline Prydnistryanske 1 & $\mathrm{IV} / 3$ & $\begin{array}{l}\text { Maturus/senilis } \\
\text { ( }+40 \text { years) }\end{array}$ & $?$ & Not done & $\mathrm{YC}$ \\
\hline Prydnistryanske 1 & $\mathrm{IV} / 4$ & $\begin{array}{l}\text { Maturus } \\
\text { (35-50 years) }\end{array}$ & Male & $\mathrm{XY}$ & $\mathrm{YC}$ \\
\hline Prydnistryanske 1 & $\mathrm{IV} / 6$ & $\begin{array}{l}\text { Maturus/senilis } \\
(45+\text { years })\end{array}$ & Male & Not done & $\mathrm{YC}$ \\
\hline Prydnistryanske 1 & $\mathrm{IV} / 8$ & $\begin{array}{l}\text { Maturus } \\
\text { (35-50 years) }\end{array}$ & Male & Not done & $\mathrm{YC}$ \\
\hline Prydnistryanske 1 & IV/9 & $\begin{array}{l}\text { Adultus } \\
\text { (25-35 years) }\end{array}$ & Male & $\mathrm{XY}$ & $\mathrm{YC}$ \\
\hline Prydnistryanske 1 & $\mathrm{IV} / 10$ & $\begin{array}{l}\text { Adultus } \\
\text { (20+ years) }\end{array}$ & $?$ & Not done & Eneolithic \\
\hline
\end{tabular}


Frequencies of health status indicators

\begin{tabular}{|c|c|c|c|c|c|c|c|c|c|c|c|c|c|}
\hline \multirow{2}{*}{ Site } & \multirow{2}{*}{ Age } & \multicolumn{3}{|c|}{$\mathrm{CO}$} & \multicolumn{3}{|c|}{ HP } & \multicolumn{3}{|c|}{$\mathrm{LEH}^{1}$} & \multicolumn{3}{|c|}{ Caries $^{1}$} \\
\hline & & $\mathbf{N}$ & n & $\%$ & $\mathbf{N}$ & $\mathbf{n}$ & $\%$ & $\mathbf{N}$ & n & $\%$ & $\mathbf{N}$ & n & $\%$ \\
\hline \multirow[t]{3}{*}{ Pidlisivka 1} & Subadult & 2 & 0 & 0.0 & 1 & 0 & 0.0 & 2 & 1 & 50.0 & 2 & 0 & 0.0 \\
\hline & Adult & 3 & 0 & 0.0 & 3 & 0 & 0.0 & 6 & 3 & 50.0 & 7 & 1 & 14.3 \\
\hline & Total & 5 & 0 & 0.0 & 4 & 0 & 0.0 & 8 & 4 & 50.0 & 9 & 1 & 11.1 \\
\hline \multirow[t]{3}{*}{ Klembivka 1} & Subadult & 1 & 0 & 0.0 & 1 & 0 & 0.0 & 2 & 1 & 50.0 & 2 & 0 & 0.0 \\
\hline & Adult & 4 & 0 & 0.0 & 2 & 1 & 50.0 & 2 & 0 & 0.0 & 5 & 2 & 40.0 \\
\hline & Total & 5 & 0 & 0.0 & 3 & 1 & 33.3 & 4 & 1 & 25.0 & 7 & 2 & 28.6 \\
\hline \multirow[t]{3}{*}{ Porohy 3A } & Subadult & 2 & 1 & 50.0 & 0 & 0 & 0.0 & 0 & 0 & 0.0 & 0 & 0 & 0.0 \\
\hline & Adult & 5 & 0 & 0.0 & 2 & 1 & 50.0 & 4 & 1 & 25.0 & 5 & 1 & 20.0 \\
\hline & Total & 7 & 1 & 14.3 & 2 & 1 & 50.0 & 4 & 1 & 25.0 & 5 & 1 & 20.0 \\
\hline \multirow{3}{*}{$\begin{array}{l}\text { Prydnistryan- } \\
\text { ske } 1\end{array}$} & Subadult & 1 & 0 & 0.0 & 0 & 0 & 0.0 & 1 & 1 & 100.0 & 1 & 0 & 0.0 \\
\hline & Adult & 6 & 1 & 16.7 & 2 & 0 & 0.0 & 4 & 0 & 0.0 & 8 & 2 & 25.0 \\
\hline & Total & 7 & 1 & 14.3 & 2 & 0 & 0.0 & 5 & 1 & 20.0 & 9 & 2 & 22.2 \\
\hline
\end{tabular}

${ }^{1}$ data for permanent teeth; $\mathrm{N}$ - number of individuals included in the study; $\mathrm{n}$ - number of individuals in whom a given indicator was observed; \% - percentage of individuals in whom a given indicator was observed

4. SUMMARY

4.1. STATE OF HEALTH ANALYSIS

For the purpose of evaluating the status of health of the human population under investigation, the following indicators were used: linear enamel hypoplasia (LEH), cribra orbitalia $(\mathrm{CO})$, porotic hyperostosis $(\mathrm{PH})$ and dental caries. Table 6 presents the frequencies of indictors for individual sites divided into adults and children.

In the studied group, LEH was observed in 7 among 21 individuals whose permanent teeth were available for examination, which represents 33.33 per cent. LEH indicates nutrient deficiencies and infectious deceases in early childhood [Goodman et al. 1980; Lanphear 1990]. In turn, the reconstruction of the time when hypoplastic defects occurred informs about the period when the child was particularly exposed to detrimental environmental factors. In the studied group the 
1
$\frac{1}{0}$
0
1

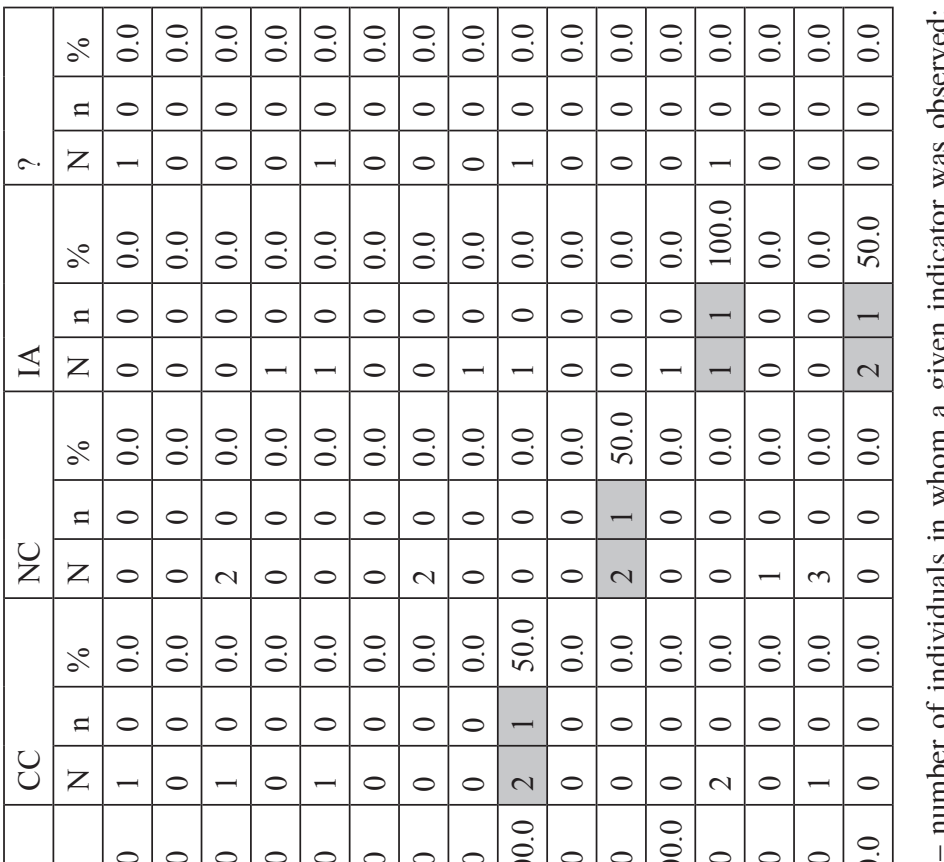

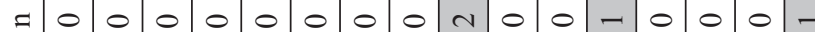

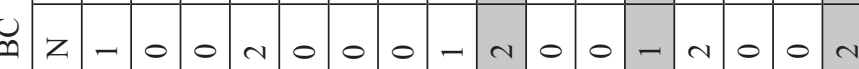

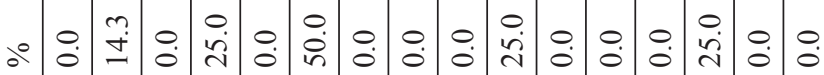

$=0-0-0-000-000-00$

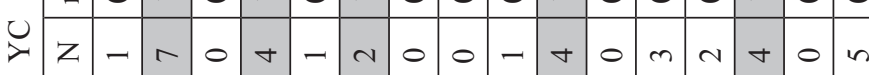

\begin{tabular}{|c|c|c|c|c|c|c|c|c|c|c|c|c|c|}
\hline & $0^{\circ}$ & $\stackrel{0}{\circ}$ & : & $\because$ & $\because$ & $\stackrel{9}{\circ}$ & $\begin{array}{l}\dot{0} \\
\dot{0}\end{array}$ & $\mid \begin{array}{l}0 \\
\dot{8} \\
0\end{array}$ & $\stackrel{\circ}{\circ}$ & $\because$ & $\stackrel{0}{0}$ & 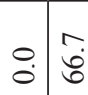 & $\because$ \\
\hline 寻 & $=$ & 0 & 0 & 0 & 0 & 0 & -0 & - & 00 & 0 & 0 & $0 \mid \mathrm{d}$ & 0 \\
\hline 矛 & z & - & 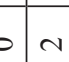 & 10 & 0 & 0 - & -0 & -1 & 0 & 0 & - & $0 \mathrm{~m}$ & 0 \\
\hline 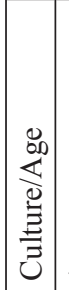 & & 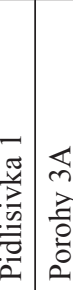 & 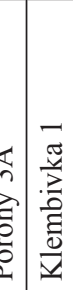 & 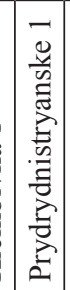 & 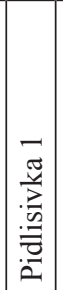 & 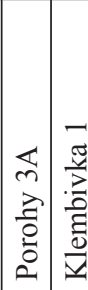 & 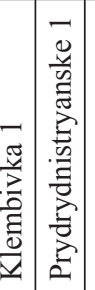 & 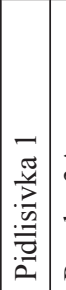 & 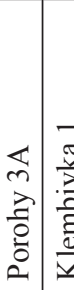 & 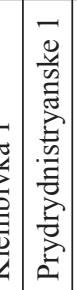 & 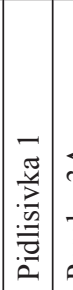 & 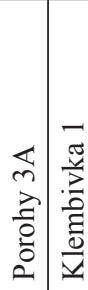 & 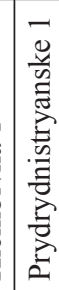 \\
\hline & & J & & & 引 & & & & & & & & \\
\hline
\end{tabular}

泀

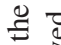


largest number of defects occurred at the ages of 2.5-3.0 and 4.5-5.0. It was at these ages that young individuals were subjected to the strongest stressors.

In the examined skeletal material, cribra orbitalia was observed only in 2 out of 24 individuals included in the study (8.3\%). These lesions are believed to be related to various types of anaemia (resulting, for instance, from iron deficiency in food). The low value of this stress indicator may show that the population under investigation did not suffer much from iron deficiency in their diet. This view is supported by a relatively low incidence of porotic hyperostosis (19\%). These lesions, similarly to cribra orbitalia, are identified with bone marrow hypertrophy caused by anaemia [Cohen, Armelagos 1984]. ${ }^{3}$

Out of 30 examined individuals having permanent teeth, 6 were found to have had caries $(20 \%)$. In the population under investigation, caries was recorded on 11 out of 553 teeth (4.5\%). Carious defects are commonly linked to a sugar-rich diet. Higher caries incidence is attributed to the consumption of carbohydrate-rich foods, while its low incidence is commonly associated with a sugar-poor diet. ${ }^{4}$ The small number of individuals with caries suggests that the examined population may have subsisted on a diet of largely animal-derived food [Turner 1979].

Table 7 shows the incidence of individual state of health indicators divided according to the cultural affiliation of individuals. Cribra orbitalia was found only in the representatives of the Yamnaya culture $(n=2, N=12)$. Porotic hyperostosis was found in the individuals of the Endolithic $(n=1, N=1)$ and $Y C(n=1, N=3)$. LEH on permanent teeth was found in Endolithic individuals $(n=1, N=3), Y C(n=1, N=8)$, CC ones $(n=3, N=3)$, BC ones $(n=1, N=2)$ and $N C(n=1, N=2)$. Tooth caries on permanent teeth was recorded in the individuals of the Eneolitic $(n=2, N=4), Y C(n=1$, $\mathrm{N} 11), \mathrm{CC}(\mathrm{n}=1, \mathrm{~N}=4)$ and those dated to the Iron Age $(\mathrm{n}=2, \mathrm{~N}=3)$. Unfortunately, it cannot be determined if there were any statistically significant differences between the state of health of individuals representing various archaeological cultures due to the meagreness of materials available for examination.

\footnotetext{
3 More recent research shows that such lesions may also result from nutrient deficiencies (vitamins B12, B6, C, D, and folic acid), parasite activity or diarrhoea [Lallo et al. 1977; Mensforth et al. 1978; Facchini et al. 2004; Cucina et al. 2006; Walker et al. 2009].

4 This is a result of the fact that microorganisms found in the dental plaque, when they metabolize carbohydrates, produce organic acids which, in turn, lower the $\mathrm{pH}$ of the mouth. This damages tooth tissues and brings about caries [Powel 1985; Šlaus et al. 2010]. Whereas populations relying for their diet on animal-derived food are characterized by a low incidence of carious defects, because proteins and calcium contained in it protects teeth against their development [Pedersen 1938; Turner 1979; Walker, Erlandson 1982].
} 
Molecular sex determination. Examinations were performed on individuals chronologically related to the 4 th/3rd and 2 nd millennia BC. We were able to confidently determine molecular sex for 10 specimens involving two individuals from Pidlisivka 1, two individuals from Porohy $3 \mathrm{~A}$, two individuals from Klembivka 1 and four individuals from Prydnistryanske 1 (see Table 1 for locations and Table 2-5 for results). Estimated $R_{\mathrm{Y}}$ values were lower than 0.016 in females and higher than 0.075 in males [Skoglund et al. 2013]. For each individual, molecular sex identification was in accordance with anthropological determinations (Pidlisivka 1/16, Porohy 3A/12 skeleton 1, Prydnistryanske I/4 and Prydnistryanske I/4 skeleton 2). For additional two individuals, molecular sex identification strengthened previous uncertain morphological assessments (Pidlisivka Feature 13 and Prydnistryanske I/4 skeleton 2). In three cases, two 12-15 year-old-children and an adult, sex was estimated solely by molecular analyses (Klembivka $1 / 12$, Porohy $3 \mathrm{~A} / 20$ skeleton 2 and Prydnistryanske I/4 skeleton 1). The state of bone preservation was very poor among these individuals. The two sex assessment methods gave contradicting results for one individual (Klembivka 1/11). This type of discordance between the methods has been noticed also in other studies [eg. Skoglund et al. 2013, Allentoft et al. 2015, Mathieson et al. 2015]. Varying degrees of bone preservation in diagnostic bone elements and differences between modern reference populations and the ancient populations investigated, could, for example result in morphological misclassifications [Kjellström 2004].

CONCLUSIONS

Health status indicators were recorded in a relatively small number of individuals among those included in the study, which could indicate their relatively good health and confirm that the community in question relied chiefly on animal products for their diet. However, it must be noted that the meagreness of the skeletal material, its poor state of preservation as well as the broad chronological range, prevent us from drawing any definite conclusions at this stage of research.

Building a complete picture of the biological structure of the Yamnaya culture community calls for further research. Only a greater number of analyzed individuals will make any firm conclusions concerning the community possible. 
Molecular sex determination is an important complement to the anthropological sex assessments. This is especially true for young individuals that can be difficult to determine morphologically as well as for individuals that lack preserved diagnostic features. Although next-generation sequencing is costly in general, quite little sequence data is needed for molecular sex determination purposes. 
SUPPLEMENT 1

Number of individuals studied from to the Eneolithic and Bronze Age

\begin{tabular}{|l|l|l|l|l|l|l|}
\hline \multirow{2}{*}{ Site } & \multicolumn{2}{|l|}{ Children } & \multicolumn{2}{l|}{ Adults } & Total \\
\cline { 2 - 7 } & $\mathbf{N}$ & $\mathbf{\%}$ & $\mathbf{N}$ & $\mathbf{\%}$ & $\mathbf{N}$ & \% \\
\hline Pidlisivka 1 & 6 & 35.3 & 6 & 15.0 & 12 & 22.2 \\
\hline Klembivka 1 & 3 & 17.6 & 8 & 20.0 & 11 & 20.4 \\
\hline Porohy 3A & 5 & 29.4 & 14 & 35.0 & 19 & 35.2 \\
\hline $\begin{array}{l}\text { Prydnistryan- } \\
\text { ske 1 }\end{array}$ & 2 & 11.8 & 10 & 58.9 & 12 & 22.2 \\
\hline Total & 16 & 29.6 & 38 & 70.4 & 54 & 100.0 \\
\hline
\end{tabular}

SUPPLEMENT 2

Basic information for antropological description

\begin{tabular}{|l|l|l|l|l|l|l|l|}
\hline & $\begin{array}{l}\text { Archaeological } \\
\text { site }\end{array}$ & Grave & Age & CO & HP & LEH & $\begin{array}{l}\text { Car- } \\
\text { ies }\end{array}$ \\
\hline 1 & Pidlisivka 1 & Barrow 1 Mound & Subadult & + & + & + & + \\
\hline 2 & Pidlisivka 1 & $\begin{array}{l}\text { Barrow 1 Feature 1a } \\
\text { Skeleton 1 }\end{array}$ & Subadult & - & - & - & - \\
\hline 3 & Pidlisivka 1 & $\begin{array}{l}\text { Barrow 1 Feature 1a } \\
\text { Skeleton 2 }\end{array}$ & Adult & - & - & - & + \\
\hline 4 & Pidlisivka 1 & Barrow 1 Feature 1b & Adult & - & - & + & + \\
\hline 5 & Pidlisivka 1 & Barrow 1 Feature 4 & Subadult & - & - & + & + \\
\hline 6 & Pidlisivka 1 & Barrow 1 Feature 5 & Adult & + & - & + & + \\
\hline 7 & Pidlisivka 1 & Barrow 1 Feature 7 & Adult & + & - & + & + \\
\hline 8 & Pidlisivka 1 & Barrow 1 Feature 8 & Subadult & - & - & - & - \\
\hline 9 & Pidlisivka 1 & Barrow 1 Feature 9 & Subadult & - & - & - & - \\
\hline 10 & Pidlisivka 1 & Barrow 1 Feature 10 & Subadult & + & - & - & - \\
\hline 11 & Pidlisivka 1 & Barrow 1 Feature 11 & Adult & + & + & + & + \\
\hline 12 & Pidlisivka 1 & Barrow 1Feature 12 & Adult & - & + & + & + \\
\hline 13 & Pidlisivka 1 & Barrow 1 Feature 13 & Adult & - & + & + & + \\
\hline 14 & Klembivka 1 & Barrow 1 Feature 2 & Adult & - & - & - & - \\
\hline 15 & Klembivka 1 & Barrow 1 Feature 3 & Adult & + & - & - & + \\
\hline
\end{tabular}




\begin{tabular}{|c|c|c|c|c|c|c|c|}
\hline 16 & Klembivka 1 & Barrow 1 Feature 5 & Adult & + & - & - & + \\
\hline 17 & Klembivka 1 & $\begin{array}{l}\text { Barrow } 1 \text { Feature } 7 \\
\text { Skeleton } 1\end{array}$ & Adul & - & - & - & - \\
\hline 18 & Klembivka 1 & $\begin{array}{l}\text { Barrow } 1 \text { Feature } 7 \\
\text { Skeleton } 2\end{array}$ & Subadult & - & - & - & - \\
\hline 19 & Klembivka 1 & $\begin{array}{l}\text { Barrow } 1 \text { Feature } 7 \\
\text { Skeleton } 3\end{array}$ & Adult & - & - & - & + \\
\hline 20 & Klembivka 1 & Barrow 11 Feature 11 & Adult & + & + & + & + \\
\hline 21 & Klembivka 1 & Barrow 1 Feature 12 & Subadult & + & + & + & + \\
\hline 22 & Klembivka 1 & Barrow 1 Feature 13 & Adult & - & - & - & - \\
\hline 23 & Klembivka 1 & Barrow 1 Feature 14 & Adult & + & + & + & + \\
\hline 24 & Klembivka 1 & Barrow 1 Feature 15 & Subadult & - & - & + & + \\
\hline 25 & Porohy $3 \mathrm{~A}$ & Barrow 3 Feature 1 & Adult & - & - & - & - \\
\hline 26 & Porohy $3 \mathrm{~A}$ & Barrow 3 Feature 2 & Adult & - & - & - & - \\
\hline 27 & Porohy $3 \mathrm{~A}$ & Barrow 3 Feature 3 & Subadult & - & - & - & - \\
\hline 28 & Porohy $3 \mathrm{~A}$ & Barrow 3 Feature 5 & Adult & - & - & - & - \\
\hline 29 & Porohy $3 \mathrm{~A}$ & Barrow 3 Feature 7 & Adult & - & - & - & + \\
\hline 30 & Porohy $3 \mathrm{~A}$ & Barrow 3 Feature 8 & Adult & - & - & - & - \\
\hline 31 & Porohy $3 \mathrm{~A}$ & Barrow 3 Feature 10 & Adult & + & + & + & + \\
\hline 32 & Porohy $3 \mathrm{~A}$ & Barrow 3 Feature 11 & Adult & + & - & + & + \\
\hline 33 & Porohy $3 \mathrm{~A}$ & $\begin{array}{l}\text { Barrow } 3 \text { Feature } 12 \\
\text { Skeleton } 1\end{array}$ & Adult & + & + & + & + \\
\hline 34 & Porohy $3 \mathrm{~A}$ & $\begin{array}{l}\text { Barrow } 3 \text { Feature } 12 \\
\text { Skeleton } 2\end{array}$ & Subadult & + & - & - & - \\
\hline 35 & Porohy $3 \mathrm{~A}$ & Barrow 3 Feature 2/14 & Subadult & - & - & - & - \\
\hline 36 & Porohy $3 \mathrm{~A}$ & Barrow 3 Feature 2/14 & Adult & - & - & - & - \\
\hline 37 & Porohy $3 \mathrm{~A}$ & Barrow 3 Feature 15 & Adult & + & - & + & + \\
\hline 38 & Porohy 3A & Barrow 3 Feature 17 & Adult & + & - & - & - \\
\hline 39 & Porohy $3 \mathrm{~A}$ & Barrow 3 Feature 18 & Subadult & - & - & - & - \\
\hline 40 & Porohy 3A & Barrow 3 Feature 19 & Subadult & + & - & - & - \\
\hline 41 & Porohy 3A & $\begin{array}{l}\text { Barrow } 3 \text { Feature } 20 \\
\text { Skeleton } 1\end{array}$ & Adult & - & - & - & - \\
\hline 42 & Porohy 3A & $\begin{array}{l}\text { Barrow } 3 \text { Feature } 20 \\
\text { Skeleton } 2\end{array}$ & Adult & - & - & - & - \\
\hline 43 & Porohy 3A & Barrow 3 Feature 21 & Adult & - & - & - & - \\
\hline 44 & Porohy $3 \mathrm{~A}$ & Barrow 3 Feature 22 & Adult & - & - & - & - \\
\hline 45 & Prydnistryanske 1 & Barrow 1 Feature 2 & Subadult & - & - & - & - \\
\hline 46 & Prydnistryanske 1 & Barrow 1 Feature 3 & Adult & + & + & - & + \\
\hline 47 & Prydnistryanske 1 & $\begin{array}{l}\text { Barrow } 1 \text { Feature } 4 \\
\text { Skeleton } 1\end{array}$ & Subadult & + & - & + & + \\
\hline
\end{tabular}




\begin{tabular}{|l|l|l|l|l|l|l|l|}
\hline 48 & Prydnistryanske 1 & $\begin{array}{l}\text { Barrow 1 Feature 4 } \\
\text { Skeleton 2 }\end{array}$ & Adult & + & + & - & + \\
\hline 49 & Prydnistryanske 1 & Barrow 2 Feature 3 & Adult & - & - & - & - \\
\hline 50 & Prydnistryanske 1 & Barrow 3 Feature 1 & Adult & - & - & - & - \\
\hline 51 & Prydnistryanske 1 & $\begin{array}{l}\text { Barrow 3 Feature 2 } \\
\text { Skeleton 1 }\end{array}$ & Adult & - & - & - & - \\
\hline 52 & Prydnistryanske 1 & $\begin{array}{l}\text { Barrow 3 Feature 2 } \\
\text { Skeleton 2 }\end{array}$ & Subadult & - & - & - & - \\
\hline 53 & Prydnistryanske 1 & Barrow 3 Feature 3 & Adult & - & - & - & - \\
\hline 54 & Prydnistryanske 1 & Barrow 3 Feature 4 & Adult & - & - & + & + \\
\hline 55 & Prydnistryanske 1 & Barrow 4 Feature 1 & Adult & - & - & - & - \\
\hline 56 & Prydnistryanske 1 & Barrow 4 Feature 3 & Adult & + & - & - & + \\
\hline 57 & Prydnistryanske 1 & Barrow 4 Feature 4 & Adult & + & - & + & + \\
\hline 58 & Prydnistryanske 1 & Barrow 4 Feature 6 & Adult & + & - & - & + \\
\hline 59 & Prydnistryanske 1 & Barrow 4 Feature 8 & Adult & + & - & + & + \\
\hline 60 & Prydnistransk & Barrow 4 Feature 9 & Adult & - & - & + & + \\
\hline 61 & Prydnistryanske 1 & Barrow 4 Feature 10 & Adult & - & - & - & - \\
\hline Total & & & & 23 & 11 & 21 & 30 \\
\hline
\end{tabular}

Translated by Piotr T. Żebrowski 


\section{REFERENCES}

Allentoft M.E., Sikora M., Sjögren K.G., Rasmussen S., Rasmussen M., Stenderup J., Damgaard P.B., Schroeder H., Ahlström T., Vinner L., Malaspinas A.S., Margaryan A., Higham T., Chivall D., Lynnerup N., Harvig L., Baron J., Della Casa P., Dąbrowski P., Duffy P.R., Ebel A.V., Epimakhov A., Frei K., Furmanek M., Gralak T., Gromov A., Gronkiewicz S., Grupe G., Hajdu T., Jarysz R., Khartanovich V., Khokhlov A., Kiss V., Koláŕ J., Kriiska A., Lasak I., Longhi C., Mc Glynn G., Merkevicius A., Merkyte I., Metspalu M., Mkrtchyan R., Moiseyev V., Paja L., Pálfi G., Pokutta D., Pospieszny Ł., Price T.D., Saag L., Sablin M., Shishlina N., Smrčka V., Soenov V.I., Szeverényi V., Tóth G., Trifanova S.V., Varul L., Vicze M., Yepiskoposyan L., Zhitenev V., Orlando L., Sicheritz-Pontén P., Brunak S., Nielsen R., Kristiansen K., Willerslev E.

2015 Population genomics of Bronze Age Eurasia. Nature 522(7555): 167-172.

Anthon D.W.

2007 The Horse, the Wheel, the Language: How Bronze-Age Riders from the Eurasian Steppes the Modern World. Oxford.

Baker B.J., Dupras T.L., Tocheri M.W.

2005 The Osteology of Infants and Children. College Station. Texas.

Bednarek R., Hildebrandt-Radke I., Jankowski M., Juras A., Kośko A., Langer J., Makohonienko M., Pietrzak S., Razumow S., Sikorski A., Żurkiewicz D.

2014 Charakterystyka źródeł archeologicznych i przyrodniczych z kurhanu Pidlisivka 1 (badania z roku 2010). In: A. Kośko, M. Potupczyk, S. Razumow (Eds), Naddniestrzańskie kompleksy cmentarzysk kurhanowych społeczności z III i z pierwszej połowy II tysiaclecia przed Chr. w okolicach Jampola, obwód winnicki. Z badań nad pótnocno-zachodniq rubieża osadnictwa społeczności kręgu kultur „wczesnobrąowych” strefy pontyjskiej. Badania z lat 1984-2014. Archaeologia Bimaris - Monografie 6, 205-297. Poznań.

Buikstra J.E., Ubelaker D.H.

1994 Standards for data collection from human skeletal remains. Proceedings of a seminar at the field Museum of Natural History. Arkansas Archaeological Survey Research Series 44. Arkansas.

Cohen M.N., Armelagos G.J.

1984 Paleopathology at the Origins of Agriculture. Florida. 
Cucina A.

2002 Brief communication: diachronic investigation of linear enamel hypoplasia in prehistoric skeletal samples from Trentino, Italy. American Journal of Physical Anthropology 119(3): 283-7.

Facchini F., Rastelli E., Brasili P.

2004 Cribra orbitalia and cribra cranii in Roman skeletal remains from the Ravenna area and Rimini (I-IV century AD). International Journal of Osteoarchaeology 14(2): 126-136.

Goodman A.H., Armelagos G.J., Rose J.C.

1980 Enamel hypoplasias as indicators of stress in three prehistoric populations from Illinois. Human Biology 52(3): 515-528.

Goodman A.H., Rose J.C.

1990 Assessment of systemic physiological perturbation from dental enamel hypoplasias and associated histological structures. American Journal of Physical Anthropology 33: 59-110.

Goslar T., Klochko V.I., Kośko A., Włodarczak P., Żurkiewicz D.

2015 Chronometry of Late Eneolithic and 'Early Bronze' cultures in the Middle Dniester area: investigations of the Yampil Barrow Complex. In: A. Kośko (Ed.). Podolia as a Cultural Contact Area in the 4th/3rd-2nd Millennium BC. Baltic-Pontic Studies 20: 256-291.

Günther T., Valdiosera C., Malmström H., Ureña I., Rodriguez-Varela R., Sverrisdóttir Ó.O., Daskalaki E.A., Skoglund P., Naidoo T., Svensson E.M., Bermúdez de Castro J.M., Carbonell E., Dunn M., Storå J., Iriarte E., Arsuaga J.L., Carretero J. M., Götherström A., Jakobsson M.

2015 Ancient genomes link early farmers from Atapuerca in Spain to modernday Basques. Proc Natl Acad Sci U S A, 112: 11917-11922.

Juras A.

2014 Badania kopalnego DNA z cmentarzysk społeczności „wczesnobrązowych" na stanowisku Pidlisiwka 1 In: A. Kośko, M. Potupczyk, S. Razumow (Eds), Naddniestrzańskie kompleksy cmentarzysk kurhanowych społeczności z II $i$ z pierwszej połowy II tysiąclecia przed Chr. $w$ okolicach Jampola, obwód winnicki. Z badań nad pótnocno-zachodnia rubieża osadnictwa spoteczności kręgu kultur „wczesnobrązowych” strefy pontyjskiej. Archaeologia Bimaris - Monografie 6, 297-300. Poznań.

Juras A., Dabert M., Kushniarevich A., Malmström H., Raghavan M., Kosicki J.Z., Metspalu E., Willerslev E., Piontek J.

2014 Ancient DNA Reveals Matrilineal Continuity in Present-Day Poland over the Last Two Millennia. PLoS ONE: 9(10):e110839. 
Kircher M.

2012 Analysis of high-throughput ancient DNA sequencing data. Methods in Molecular Biology 840: 197-228.

Kjellström A.

2004 Evaluations of Sex Assessment using Weighted Traits on Incomplete Skeletal Remains. International Journal of Osteoarchaeology 14: 360-373.

Kośko A., Potupczyk M., Razumow S. (Eds)

2014 Naddniestrzańskie kompleksy cmentarzysk kurhanowych społeczności z III $i$ z pierwszej połowy II tysiqclecia przed Chr. w okolicach Jampola, obwód winnicki. $Z$ badań nad pótnocno-zachodniq rubieża osadnictwa społeczności kręgu kultur „wczesnobrazowych” strefy pontyjskiej. Badania z lat 1984-2014. Archaeologia Bimaris - Monografie 6. Poznań.

Klochko V.I., Kośko A., Potupchyk M.V., Włodarczak P., Żurkiewicz D., Ivanova S.V.

2015 Tripolye (Gordineşti group), Yamnaya and Catacomb culture cemeteries, Prydnistryanske, site 1, Yampil Region, Vinnitsa Oblast: an archaeometric and chronometric description and a taxonomic and topogenetic discussion. In: A. Kośko (Ed.) Podolia as a Cultural Contact Area in the 4th/3rd-2nd Millennium BC. Baltic-Pontic Studies 20: 183-255.

Klochko V.I., Kośko A., Razumov S.M., Włodarczak P., Żurkiewicz D.

2015a Eneolithic, Yamnaya, Catacomb and Babyno culture cemeteries, Pidlisivka, barrow 1, Yampil Region, Vinnitsa Oblast: archaeometry, chronometry and taxonomy. In: A. Kośko (Ed.) Podolia as a Cultural Contact Area in the 4th/3rd-2nd Millennium BC. Baltic-Pontic Studies 20: 40-77.

2015b Eneolithic, Yamnaya and Noua culture cemeteries from the first half of the 3rd and the middle of the 2nd millennium BC, Porohy, site 3a, Yampil Region, Vinnitsa Oblast: archaeometric and chronometric description, ritual and taxonomic-topogenetic identification. In: A. Kośko (Ed.) Podolia as a Cultural Contact Area in the 4th/3rd-2nd Millennium BC. Baltic-Pontic Studies 20: 78-141.

2015c Eneolithic, Babyno and Noua culture cemeteries, Klembivka, site 1, Yampil Region, Vinnitsa Oblast: archaeometry, taxonomy and topogenetics. In: A. Kośko (Ed.) Podolia as a Cultural Contact Area in the 4th/3rd-2nd Millennium BC. Baltic-Pontic Studies 20: 142-182.

Lallo J.W., Armelagos G.J., Mensforth R.P.

1977 The role of diet, disease, and physiology in the origin of porotic hyperostosis. Human Biology 49(3): 471-83. 
Lanphear K.M.

1990 Frequency and distribution of enamel hypoplasias in a historic skeletal sample. American Journal of Physical Anthropology 81(1): 35-43.

Li H., Durbin R.

2009 Fast and accurate short read alignment with Burrows-Wheeler transform. Bioinformatics 25(14): 1754-1760.

Li H., Handsaker B., Wysoker A., Fennell T., Ruan J., Homer N., Marth G., Abecasis G., Durbin R.

2009 The Sequence Alignment/Map format and SAM tools. Bioinformatics 25(16): 2078-2079.

Mathieson I., Lazaridis I., Rohland N., Mallick S., Patterson N., Roodenberg S.A., Harney E., Stewardson K., Fernandes D., Novak M., Sirak K., Gamba C., Jones E.R., Llamas B., Dryomov S., Pickrell J., Arsuaga J.L., de Castro J.M., Carbonell E., Gerritsen F., Khokhlov A., Kuznetsov P., Lozano M., Meller H., Mochalov O., Moiseyev V., Guerra M.A., Roodenberg J., Vergès J.M., Krause J., Cooper A., Alt K.W., Brown D., Anthony D., Lalueza-Fox C., Haak W., Pinhasi R., Reich D.

2015 Genome-wide patterns of selection in 230 ancient Eurasians. Nature 528(7583): 499-503.

Mensforth R.P., Lovejoy C.O., Lallo J.W., Armelagos G.J.

1978 Part Two: The role of constitutional factors, diet, and infectious disease in the etiology of porotic hyperostosis and periosteal reactions in prehistoric infants and children. Medical Anthropology 2(1): 1-59.

Meyer M, Kircher M.

2010 Illumina sequencing library preparation for highly multiplexed target capture and sequencing. Cold Spring Harb Protoc 6: t5448.

Molnar P., Ahlstrom T.P., Leden I.

2011 Osteoarthritis and Activity - An Analysis of the Relationship between Eburnation, Musculoskeletal Stress Markers (MSM) and Age in Two Neolithic Hunter-Gatherer Populations from Gotland, Sweden. International Journal of Osteoarchaeology 21: 283-291.

Pedersen P.O.

1938 Investigations into dental conditions of about 3000 ancient and modern Greenlanders. Dental record 24(7): 702-704.

Powel M.L.

1985 The Analysis of Dental Wear and Caries for Dietary Reconstruction. In: 
R.I. Gilbert, J.H. Mielke (Eds), The Analysis of Prehistoric Diets, 307-338. Orlando.

Schaefer M., Black S., Scheuer L.

2009 Juvenile Osteology: a Laboratory and Field Manual. Oxford.

Skoglund P., Storå J., Götherström A., Jakobsson M.

2013 Accurate sex identification of ancient human remains using DNA shotgun sequencing. Journal of Archaeological Science 40: 4477-4482.

Steckel H., Larsen C.S., Sciulli P.W., Walker P.L.

2005 Data collection codebook. The Global History of Health Project http:// global.sbs.ohio-state.edu/docs/Codebook-12-12-05.pdf.

Svensson E.M., Anderung C., Baubliene J., Persson P., Malmström H., Smith C., Vretemark M., Daugnora L., Götherström A.

2007 Tracing genetic change over time using nuclear SNPs in ancient and modern cattle. Animal Genetics 38: 378-383.

Šlaus M., Bedić Ž., Rajić Šikanjić P., Vodanović M., Domić - Kunić A.

2010 Dental health at the transition from the Late Antique to the early Medieval period on Croatia's eastern Adriatic coast. International Journal of Osteoarchaeology 21(5): 577-590.

Trotter M., Gleser G.C.

1952 Estimation of stature tram long bones of American Whites and Negroes. American Journal of Physical Anthropology 10(4): 463-514.

Turner C.G.

1979 Dental anthropological indications of agriculture among the Jomon people of central Japan. X. Peopling of the Pacific. American Journal of Physical Anthropology 51(4): 619-635.

Yang D.Y., Eng D., Waye J.S., Dudar J.C., Saunders S.R.

1998 Technical note: Improved DNA extraction from ancient bones using silica based spin columns. American Journal of Physical Anthropology 105: 539-54 .

Weiss E., Jurmain R.

2007 Osteoarthritis Revised: A Contemporary Review of Etiology. International Journal of Osteoarchaeology 17: 437-450.

Walker P.L., Erlandson J.M.

1986 Dental evidence for prehistoric dietary change on the northern Channel Islands, California. American Antiquity 51(2): 375-83. 
Walker P.L., Bathurst R.R., Richman R., Gjerdrum T., Andrushko V.A.

2009 The Causes of Porotic Hyperostosis and Cribra orbitalia: A Reappraisal of the Iron-Deficiency-Anemia Reappraisal of the Iron-Deficiency-Anemia Hypothesis. American Journal of Physical Anthropology 139(2): 109-25.

White T.D., Folkens P.A.

2005 The human bone manual. Oxford. 